\title{
Active management is required to turn the tide for depleted Ostrea edulis stocks from the effects of overfishing, disease and invasive species
}

\author{
Luke Helmer $^{1}$, Paul Farrell ${ }^{1}$, Ian Hendy ${ }^{1,2}$, Simon Harding ${ }^{2}$, Morven Robertson ${ }^{2}$, Joanne Preston ${ }^{\text {Corresp. }}$ \\ ${ }^{1}$ Institute of Marine Sciences, University of Portsmouth, Portsmouth, Hampshire, United Kingdom \\ 2 Blue Marine Foundation, London, United Kingdom \\ Corresponding Author: Joanne Preston \\ Email address: joanne.preston@port.ac.uk
}

The decline of the European oyster Ostrea edulis across its biogeographic range has been driven largely by over-fishing and anthropogenic habitat destruction, often to the point of functional extinction. However, other negatively interacting factors attributing to this catastrophic decline include disease, invasive species and pollution. In addition, a relatively complex life history characterised by sporadic spawning renders 0 . edulis biologically vulnerable to over-exploitation. As a viviparous species, successful reproduction in 0 . edulis populations is density dependent to a greater degree than broadcast spawning oviparous species such as the Pacific oyster Crassostrea (Magallana) gigas. Here we report on the benthic assemblage of $O$. edulis and the invasive gastropod Crepidula fornicata across three actively managed South coast harbours in one of the few remaining $O$. edulis fisheries in the UK. Long-term data reveals that numbers of $O$. edulis sampled within Chichester Harbour have decreased by $96 \%$, in contrast numbers of $C$. fornicata sampled have increased by $441 \%$ over a 19 -year period. The recent survey data also recorded extremely low densities of $O$. edulis, and extremely high densities of $C$. fornicata, within Portsmouth and Langstone Harbours. The native oyster's failure to recover, despite fishery closures, suggests competitive exclusion by $C$. fornicata is preventing recovery of $O$. edulis, which is thought to be due to a lack of habitat heterogeneity or suitable settlement substrate. Large scale population data reveals that mean $O$. edulis shell length and width has decreased significantly across all years and site groups from 2015 to 2017, with a narrowing demographic structure. An absence of juveniles and lack of multiple cohorts in the remaining population suggests that the limited fishing effort exceeds biological output and recruitment is poor. In the Langstone \& Chichester 2017 sample $98 \%$ of the population is assigned to a single cohort (modal mean $71.20 \pm 8.78 \mathrm{~mm}$, maximum length). There is evidence of small scale $(<5 \mathrm{~km})$ geographic population structure between connected harbours; the 2015 Portsmouth and Chichester 
fishery populations exhibited disparity in the most frequent size class with $36 \%$ within 81 $90 \mathrm{~mm}$ and $33.86 \%$ within $61-70 \mathrm{~mm}$ respectively, the data also indicates a narrowing demographic over a short period of time. The prevalence of the disease Bonamiosis was monitored and supports this microgeographic population structure. Infection rates of $O$. edulis by Bonamia ostreae was $0 \%$ in Portsmouth Harbour $(n=48), 4.1 \%$ in Langstone $(n=145)$ and $21.3 \%$ in Chichester $(n=48)$ populations. These data collectively indicate that $O$. edulis is on the brink of an ecological collapse within the Solent harbours. Without effective intervention to mitigate the benthic dominance by $C$. fornicata in the form of biologically relevant fishery policy and the management of suitable recruitment substrate these native oyster populations could be lost. 


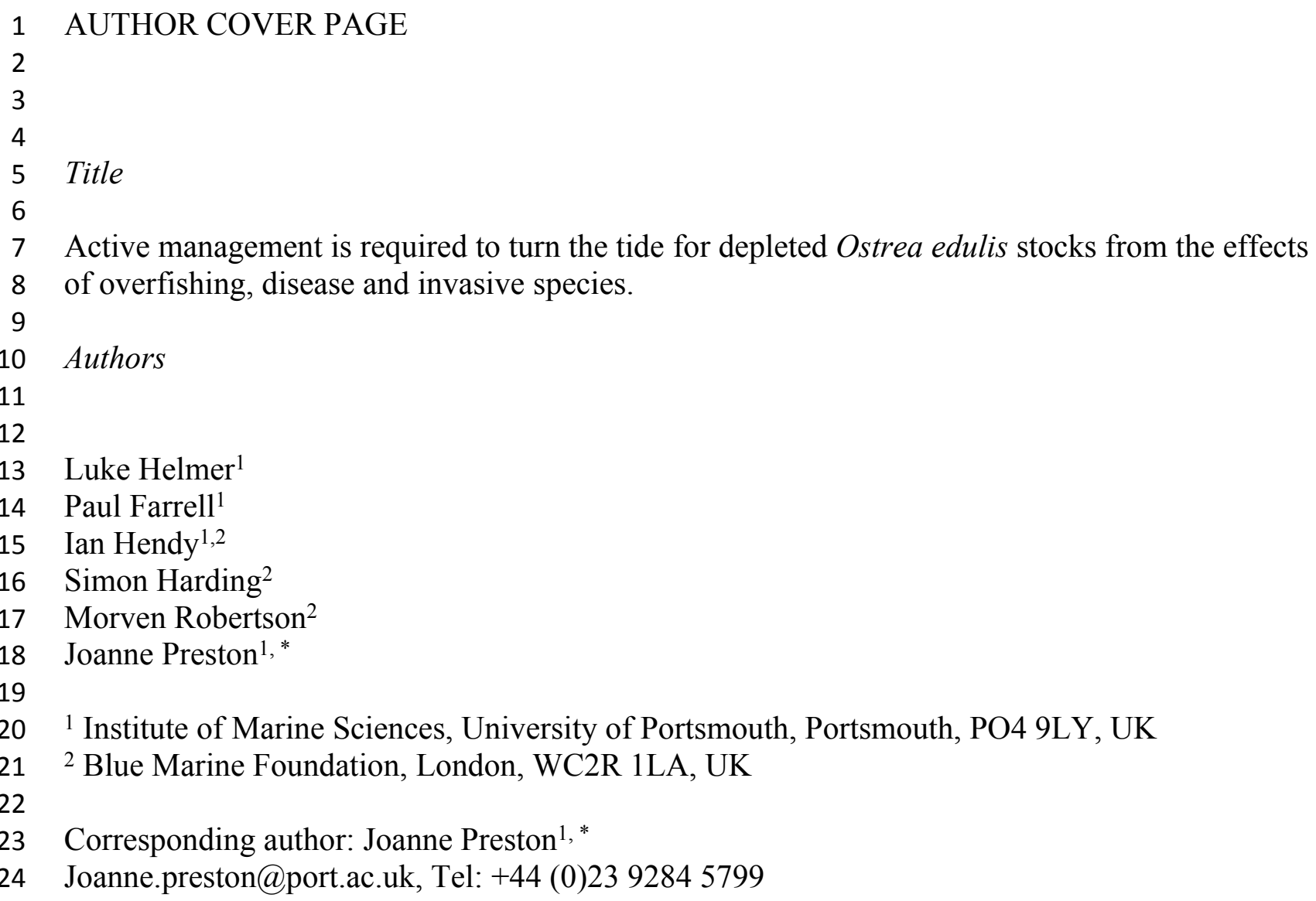




\section{ABSTRACT}

The decline of the European oyster Ostrea edulis across its biogeographic range has been driven largely by over-fishing and anthropogenic habitat destruction, often to the point of functional extinction. However, other negatively interacting factors attributing to this catastrophic decline include disease, invasive species and pollution. In addition, a relatively complex life history characterised by sporadic spawning renders $O$. edulis biologically vulnerable to overexploitation. As a viviparous species, successful reproduction in O. edulis populations is density dependent to a greater degree than broadcast spawning oviparous species such as the Pacific oyster Crassostrea (Magallana) gigas. Here we report on the benthic assemblage of $O$. edulis and the invasive gastropod Crepidula fornicata across three actively managed South coast harbours in one of the few remaining $O$. edulis fisheries in the UK. Long-term data reveals that numbers of O. edulis sampled within Chichester Harbour have decreased by $96 \%$, in contrast numbers of $C$. fornicata sampled have increased by $441 \%$ over a 19 -year period. The recent survey data also recorded extremely low densities of $O$. edulis, and extremely high densities of C. fornicata, within Portsmouth and Langstone Harbours. The native oyster's failure to recover, despite fishery closures, suggests competitive exclusion by $C$. fornicata is preventing recovery of O. edulis, which is thought to be due to a lack of habitat heterogeneity or suitable settlement substrate. Large scale population data reveals that mean $O$. edulis shell length and width has decreased significantly across all years and site groups from 2015 to 2017, with a narrowing demographic structure. An absence of juveniles and lack of multiple cohorts in the remaining population suggests that the limited fishing effort exceeds biological output and recruitment is poor. In the Langstone \& Chichester 2017 sample 98\% of the population is assigned to a single cohort (modal mean $71.20 \pm 8.78 \mathrm{~mm}$, maximum length). There is evidence of small scale $(<5$ 
$64 \mathrm{~km}$ ) geographic population structure between connected harbours; the 2015 Portsmouth and

65 Chichester fishery populations exhibited disparity in the most frequent size class with $36 \%$

66 within $81-90 \mathrm{~mm}$ and $33.86 \%$ within $61-70 \mathrm{~mm}$ respectively, the data also indicates a

67 narrowing demographic over a short period of time. The prevalence of the disease Bonamiosis

68 was monitored and supports this microgeographic population structure. Infection rates of $O$.

69 edulis by Bonamia ostreae was $0 \%$ in Portsmouth Harbour $(\mathrm{n}=48), 4.1 \%$ in Langstone $(\mathrm{n}=$

$70145)$ and $21.3 \%$ in Chichester $(n=48)$ populations. These data collectively indicate that $O$.

71 edulis is on the brink of an ecological collapse within the Solent harbours. Without effective

72 intervention to mitigate the benthic dominance by $C$. fornicata in the form of biologically

73 relevant fishery policy and the management of suitable recruitment substrate these native oyster

74 populations could be lost.

75

76

77

78

79 
80

81

82

83

84

85

86

87

88

89

90

91

92

93

94

95

96

97

98

99

100

101

102

103

\section{INTRODUCTION}

The habitat of the European flat oyster Ostrea edulis (Linnaeus, 1758) includes a range of firm substrata from the lower intertidal to subtidal depths up to 80m (Perry \& Jackson 2017) across a biogeographic range that stretches from Morocco, throughout the Mediterranean and Black seas, to Norway (Lallias et al. 2010). Earliest records identify O. edulis shell middens from the Mesolithic period, (Gutiérrez-Zugasti et al. 2011) and cultivation from the Roman Empire (Gunther 1897), illustrating the long history of extraction for human consumption. Native oyster populations throughout Britain remained large and lightly fished up until the early 19th century (Edwards 1997 , Key \& Davidson 1981). By the mid-19 ${ }^{\text {th }}$ C demand was high, approximately 700 million oysters were consumed in London during 1864, supporting a sizable UK fleet of 120,000 oyster dredgers (Philpots 1890 in Edwards 1997). In France, historic shell piles contained approximately 5x1012 oysters (Gruet \& Prigent 1986 in Goulletquer \& Heral 1997) highlighting their vast densities and the likely unsustainable extraction of this species. Despite UK governmental legislation put in place by a parliamentary committee (still enforced under the Sea Fisheries (Shellfish) Act of 1967), stocks inevitably declined. Landings of O. edulis in English and Welsh waters decreased from 3,500 tonnes in 1887, to $<500$ tonnes in 1947 (Laing et al. 2006). The distribution of O. edulis across the UK and Europe is a fraction of reported historic levels, with many historic beds completely depleted and the few remaining populations found predominantly in subtidal habitats (Gross \& Symth, 1946, Laing et al. 2005, 2006, Culloty \& Mulcahy 2007). This is a global issue with approximately $85 \%$ of the world's oyster populations and their associated habitat having been lost (Beck et al. 2011), resulting in ecological decline due to the ecosystem services oysters provide (Cranfield et al. 1999, Carbines et al. 2004). 
This decline in the native oyster is reflected in the Solent, described in detail by Key \&

105

106

107

108

109

110

111

112

113

114

115

116

117

118

119

120

121

122

123

124

125

126

Davidson (1981). Oyster cultivation within the Solent occurred from 1866 onwards, with small scale removal and relocation taking place in the early 20th century (Anon 1912-1940 in Key \&

Davidson 1981). Throughout the 1970s and early 80s the Solent was one of the larger remaining oyster fisheries in Europe, supporting 450 commercial vessels that landed 650-850 tonnes of $O$. edulis between Weymouth and Chichester during 1979-80 and recorded seabed densities of 32 / $\mathrm{m}^{2}$ (Key \& Davidson 1981). The relative ease of access to their intertidal and coastal habitat facilitated the continued unstainable extraction which, alongside a range of other environmental and anthropogenic pressures, led to chronic population decline (Davidson 1976; Key \& Davidson 1981; Tubbs 1999; Vanstaen \& Palmer 2009). At the turn of the 21 st century annual stocks had decreased rapidly from 200 to 20 tonnes by 2011, which was mirrored in the decline of fishing licences issued, from 77 (2002/3) to 22 (2009/10) (Kamphausen 2012). The Southern Inshore Fisheries and Conservation Authority (IFCA) closed the wider Solent completely between 2013 and 2015 due to a failure of stocks to recover from a population crash in 2007 (Southern IFCA 2014 in Gravestock et al. 2014). A lack of recovery that is in part due to the complex lifecycle of the species which is notoriously sporadic and comprises of multiple stages, including external sperm release, internal egg fertilisation, vulnerable free-swimming larvae and larval settlement (Fig. 1). The unsustainable impact of overfishing is further compounded by multiple detrimental factors that are summarised in Figure 2.

The disease Bonamiosis has severely impacted O. edulis populations. Caused by the intrahaemocytic protozoan parasite Bonamia ostreae, introduced into Europe via transplanted $O$. edulis seed from Californian hatcheries (MacKenzie et al. 1997), it has spread across Europe (Grizel et al. 1988, Lynch et al. 2005, Culloty \& Mulcahy 2007, Lallias et al. 2008) causing mass 
127 mortalities of up to $90 \%$ of localised populations (Figueras 1991, Cigarria et al. 1995, Laing et

128 al. 2005). The parasite becomes systemic within the host oyster, inducing physiological disorders

129 that eventually become overwhelming, causing death (Grizel et al. 1988). Although, it is thought

130 that some resistance can arise through selective breeding strategies (Baud et al. 1997, Culloty et

131 al. 2001, Lallias et al. 2009).

132 The presence of the invasive gastropod Crepidula fornicata is also a major concern 133 across Europe (Blanchard 1997), particularly in the Solent. The species was accidently

134 introduced with imports of Crassostrea virginica (Dodd 1893, McMillan 1938, Hoagland 1985, 135 Utting \& Spencer 1992, Minchin et al. 1995) and Magallana gigas (Blanchard 1997) to

136 Liverpool in the 1880's (Moore 1880 in McMillan 1938) and the east coast and Thames estuary

137 in the 1890's and early 1900's (Crouch 1893, Cole 1915). Despite claims that C. fornicata may

138 increase macrozoobenthic communities in muddy sediments (de Montaudouin \& Sauriau 2017),

139 its rapid expansion throughout many areas of the UK (Orton 1950, Chipperfield 1951, Cole \&

140 Baird 1953, Barnes et al. 1973, Minchin et al. 1995) and Europe (Blanchard 1997, 2009, Davis \&

141 Thompson 2000, Thieltges et al. 2003), including rapid colonisation of oyster beds (Crouch

142 1893), has serious ecological and economic impacts (see Blanchard 1997). Crepidula fornicata

143 has been shown to be detrimental to habitat suitability for juvenile fish (Le Pape et al. 2004),

144 suprabenthic biodiversity (Vallet et al. 2001), shell growth and survival of the bivalve Mytilus

145 edulis (Thieltges 2005). This invasive species is also attributed to habitat modification, through

146 the production of mucus pseudofaeces, whereby benthic substrata change from predominantly

147 sandy to muddy with a high organic content that rapidly becomes anoxic and unsuitable for other

148 species (Streftaris \& Zenetos 2006). This includes the native oyster through a reduction in 
149 suitable substrata available for larval settlement (Blanchard 1997), hindering recruitment and 150 potentially oyster restoration efforts on the seabed.

The shift towards a habitat dominated by $C$. fornicata, due to the decline of $O$. edulis and

152 its accompanying biogenic habitat, is also of concern because of the loss of associated socio-

153 economic benefits (Grabowski et al. 2012) and ecosystem services that other oysters species

154 have been shown to provide (Coen et al. 2007). These services include, but are not limited to, 155 increases in: biodiversity (Wells 1961, Zimmerman et al. 1989, Smyth \& Roberts 2010), habitat 156 complexity (Bell et al. 1991) nekton biomass (Humphries \& La Peyre 2015), fish abundance

157 (Coen et al. 1999, Harding \& Mann 2001, Peterson et al. 2003, Tolley \& Volety 2005) and

158 nitrogen removal (Piehler \& Smyth 2011, Kellogg et al. 2013, Smyth et al. 2013). It is

159 recommended that further research is conducted to better understand these services in relation to 160 O. edulis. The ecological significance and economic importance of this species within coastal 161 temperate environments is also highlighted by its inclusion within the UK Biodiversity Action 162 Plan (UKBAP 1999, Gardner \& Elliott 2001), which describes the habitats or species of the UK 163 and provides detailed plans for the conservation of native oysters. To add, further legislation 164 encompassing the Native Oyster Species Action Plan (NOSAP) (Hawkins et al. 2005) has been

With the global decline of oyster reefs, beds and other habitats, oyster restoration efforts are growing in momentum and scope for widespread restoration in North East Atlantic marine protected areas has been proposed (Fariñas-Franco et al. 2018). Numerous restoration feasibility studies (Laing et al. 2005; Shelmerdine \& Leslie 2009; Woolmer et al. 2011; Gravestock et al.

171 2014, Fariñas-Franco et al. 2018) and restoration projects (Roberts et al. 2005; Eagling 2012: 
172 cited in Gravestock et al. 2014; Harding et al. 2016) have been, and are currently being,

173 conducted within the UK. Laing et al. (2005, p 65-81) outlines many of the known previous

174 attempts globally with zu Ermgassen et al. (2016) outlining the management strategies for future

175 conservation efforts.

176 Current baseline data is required to understand the fundamental ecological principles of

177 distribution, density, growth, survival, reproduction and recruitment of the native oyster. The

178 importance of such data is illustrated by Christianen et al. (2018) after recently discovering a 40-

179 hectare mixed bed reef in an area where O. edulis was previously considered ecologically

180 extinct. This study, provides data on the current distribution, abundance and demographic

181 structure of $O$. edulis in the eastern Solent encompassing Portsmouth, Langstone and Chichester

182 Harbours, sites intended for future oyster restoration efforts. The health status of each population

183 is assessed using condition index and the screening of specimens for Bonamiosis infection. The

184 change in fishery stock within the local harbours is assessed as are the changes in abundance of

185 O. edulis and C. fornicata within Chichester Harbour, by comparing current and historical

186 datasets.

187

188

MATERIALS AND METHODS

189

190

\section{Demographic assessment}

191 Demographic population data from 2015 - 2017 were derived from oysters captured by

192 commissioned dredge fishing at the beginning of the open fishing season of each stated year's

193 fishery, with no selection for minimum landing size. All oysters were collected using ladder

194 dredges in accordance with the local byelaw conditions for Portsmouth and Langstone Harbours

195 (Southern Inshore Fisheries and Conservation Authority 2018) and Chichester Harbour (Sussex 
196 Inshore Fisheries and Conservation Authority 2018) IFCAs. Oysters were obtained from the

197 entrance of Portsmouth Harbour (Hamilton Bank and Spit Bank, H+S, Fig. 3A) and within

198 Chichester Harbour (Emsworth and Thorney Channels, E \& T, Fig. 3A) during November 2015.

199 Oysters from Langstone Harbour (Sinah Lake and Langstone Channel, S \& L, Fig. 3A) were

200 obtained during November 2016. Oysters from Langstone and Chichester Harbours were also

201 obtained during 2017, but unfortunately, the fishers mixed these populations on landing. Live

202 oysters were cleaned to remove epibionts and blotted dry before measuring. Measurements (Fig.

203 4A) for the maximum shell length, width and depth, as well as whole wet weight were recorded

204 for a minimum of 700 oysters from each harbour. Maximum shell depth was not recorded for the

205 first 500 Chichester and Portsmouth oysters, but was recorded for the final 200 individuals.

206

207

208

209

210

211

212

213

214

215

216

217

218

219

\section{Condition index (CI) and Bonamia ostreae prevalence:}

Oysters sampled for condition index (CI) and B. ostreae screening were immediately frozen and stored at $-20^{\circ} \mathrm{C}$. Condition index was performed to compare oyster populations from Chichester $(\mathrm{n}=24)$ and Portsmouth $(\mathrm{n}=24)$ according to the methodology in Culloty et al. $(2004, \mathrm{p} 45)$

with modifications, $105^{\circ} \mathrm{C}$ for $24 \mathrm{~h}$ opposed to $60^{\circ} \mathrm{C}$ for $48 \mathrm{~h}$. The calculation used by Walne $\&$ Mann (1975) and Lucas \& Beninger (1985) (cited in Culloty et al. (2004) was used to determine CI:

Condition index = Dry Tissue Weight / Dry Shell Weight $\mathrm{x} 100$.

In addition to the gill tissue samples taken before CI analysis, a further 24 oysters were selected at random from the landings of both harbours to determine the prevalence of $B$. ostreae infection. For each specimen a $5 \mathrm{~mm}$ section of gill tissue was removed with a sterile blade and genomic DNA extractions were performed using DNeasy® Blood \& Tissue kits (QIAGENTM product 69504) following the manufacturer's tissue protocol (Qiagen 2006). Quantification of 
220 the DNA extractions was conducted using a NanoDrop ${ }^{\circledR} 1000$ Spectrophotometer (NanoDrop ${ }^{\circledR}$,

221 Thermo Fisher Scientific Inc., Wilmington, USA). Species specific primers Oe fw_1/Oe rev_4

222 (Grecken \& Schmidt 2014) were used to amplify the cytochrome c oxidase subunit I (COI) gene

223 from oyster DNA, as a positive control. Family and species specific primers (BO / BOAS

224 (Cochennec et al. 2000) and CF / CR (Carnegie et al. 2000) were used to amplify fragments of

225 the nearly complete small sub unit (SSU) of 18S rDNA from all microcell members of the family

226 Haplosporidiidae and specifically B. ostreae.

227

228

229

Gene amplification by polymerase chain reaction (PCR) was performed in $25 \mu 1$ reactions using 1x DreamTaq ${ }^{\mathrm{TM}}$ PCR Master Mix (Thermo Fisher Scientific Inc.), $0.2 \mu \mathrm{M}$ each primer, 30 - 100 ng genomic DNA, and adjusted to the final volume with molecular grade $\mathrm{H}_{2} \mathrm{O}$. Reactions were conducted in a G-STORM 482 - 48 Well Multi Block Thermal Cycler (Gene Technologies Ltd., Essex, England) as follows. For Oe fw_1/ Oe rev_4 primers: initial denaturation for 5 minutes at $94^{\circ} \mathrm{C}, 35$ cycles of amplification $\left(1\right.$ minute denaturation at $94^{\circ} \mathrm{C}, 1$ minute annealing at $45^{\circ} \mathrm{C}$ and 1 minute extension at $72^{\circ}$ ) followed by a final extension at $72^{\circ} \mathrm{C}$ for 10 minutes. For the $\mathrm{BO} / \mathrm{BOAS}$ and $\mathrm{CF} / \mathrm{CR}$ primers: initial denaturation for 5 minutes at $94^{\circ} \mathrm{C}$ was followed by 35 cycles of amplification ( 1 minute denaturation at $94^{\circ} \mathrm{C}, 1$ minute annealing at $55^{\circ} \mathrm{C}$ and 1 minute extension at $72^{\circ}$ ) and then by a final extension step at $72^{\circ} \mathrm{C}$ for 10 minutes.

PCR products were visualised using 1\% agarose gels (Fisher Scientific, UK) composed of $100 \mathrm{ml} 1 \mathrm{X}$ Tris-acetate-EDTA (TAE) buffer and $4 \mu \mathrm{l}$ ethidium bromide (Sigma- Aldrich®). Using the GeneRuler ${ }^{\mathrm{TM}}$ 1kb DNA ladder (Thermo Fisher Scientific Inc.) for size quantification. Electrophoresis was run at $95 \mathrm{~V}$ for $1 \mathrm{~h}$. Following this the samples were visualised by ultraviolet (UV) transillumination in a 'VWR® Gel Documentation Smart Version system'. 
The oysters collected from Langstone Harbour $(n=145)$ were analysed, for presence or

246

247

248

249

250

251

252

253

254

255

256

257

258

259

260

261

262

263

264

265

266

267

\section{Ostrea edulis and Crepidula fornicata benthic surveys: 1998 and 2017}

The Chichester Harbour sample locations were identical for surveys completed in 1998 and 2017. The 1998 survey method varied from that in 2017, in that a box anchor dredge was used at 26 of the sample locations, 3 locations were hand dug at extreme low water spring tide and 2 locations were not sampled due to logistical reasons. Sample area was calculated as follows:

$$
\text { Dredge volume }=36 \text { litres, }=36000 \mathrm{~cm}^{3}
$$

Mean thickness of sediment layer $=6 \mathrm{~cm}$

Theoretical area sampled by full dredge $=36000 / 6,=6000 \mathrm{~cm} 2,=0.6 \mathrm{~m}^{2}$

The majority of the recent surveys occurred before the $1^{\text {st }}$ November 2017 in what would become the active fishery areas, other 'closed' areas in Chichester Harbour were sampled after this date. Thirty or thirty-one locations were chosen within each harbour (Fig. 3B), with three replicate samples collected using a $0.1 \mathrm{~m}^{2}$ Van-Veen grab at each location. For each sample all material collected was passed through a $6 \mathrm{~mm}$ square mesh box sieve, to remove excess sediment, and placed into individually sealed plastic bags when onboard the research vessel. Samples were then returned to the laboratory where they were rinsed and passed through a $6 \mathrm{~mm}$ square mesh box sieve for a second time to remove any remaining sediment to observe live 
268 organisms with ease. Total oyster $($ O. edulis) and limpet (C. fornicata) densities were recorded

269 for each sample location.

Geographical position was assessed with a precision of $2 \mathrm{~m}$ using a Lowrance ${ }^{\circledR}$ Elite $7 \mathrm{~m}$

271 GPS system. Distribution and abundance of oysters and slipper limpets were successfully

272 surveyed at all sites within all harbours during the 2017 survey and 29 of the 31 proposed sites

273 within Chichester Harbour in 1998.

274

\section{Data analysis}

All statistical analysis was performed in IBM ${ }^{\circledR}$ SPSS ${ }^{\circledR}$ Statistics 22 (IBM Analytics).

277

278

279

280

281

282 using one-way ANOVAs against year and site groups. Condition Index data were tested for homogeneity of variance using Levene's test and were found to be 'normal' $\left(F_{1,46}=0.9, P>\right.$ 0.05 ) and analysed using a one-way ANOVA against location. Benthic survey data collected in 2017 for limpet densities were analysed using an ANOVA general linear model (GLM) with harbour and site as independent variables. Oyster data were not suitable for statistical analysis within the ANOVA GLM. The mean densities of oysters and limpets within each harbour were compared against one another using paired student T-tests, as were the Chichester Harbour 1998 data. For comparisons between the 1998 and 2017 surveys, data were analysed for each species using an ANOVA GLM with harbour and site as independent variables. FAO-ICALARM stock assessment tools II (FiSat II) modal progression analysis of oyster length frequency distributions were used to identify distinct cohorts within each population. Minimum size class was specified at $15 \mathrm{~mm}$ with $5 \mathrm{~mm}$ size class intervals. Bhattacharya's method was used to determine initial decompose composite length-frequency distributions and refined using NORMSEP. 
292 Principle Coordinate Analysis (PCO) with data constrained in Bray Curtis similarity matrices

293

294

295

296

297

298

299

300

301

302

303

304

305

306

307

308

309

310

311

312

313

were examined using PRIMER 6.1 (PrimerE Ltd: Plymouth Routines in Multivariate Ecological

Research) to explore similarities with the relationship between the condition index, maximum shell length and infection occurrence. PCO analyses were used for visualizing the results as an ordination, constrained to linear combinations of the variables. Similarities of the condition index, maximum shell length and infection occurrences between localities were examined using PERMANOVA main tests and post-hoc pairwise tests.

\section{RESULTS}

\section{Population demographics}

The interquartile range, median and range of the populations are shown in Figure 4 B-E with statistically significant populations distinguished by lettering. There were statistically significant differences between group means across site/years (Table 1). There was a significant difference in the mean maximum length, width, depth and weight between the oyster populations in Portsmouth and Chichester Harbours in 2015. There was no significant difference in mean width or depth between the 2015 Chichester and 2016 Langstone populations. Mean length and width has decreased across sites and years since 2015; the 2017 Chichester and Langstone population has significantly smaller oysters than all previous year/site groups.

The most frequent length size class recorded from the 2015 Portsmouth population was $81-90 \mathrm{~mm}(36 \%)$ in contrast to $61-70 \mathrm{~mm}(33.86 \%)$ in the 2015 Chichester population. The latter was also the most frequent size class in the 2016 Langstone (40.57\%) and 2017 Chichester \& Langstone samples (40.69\%). The most frequent maximum shell width size class was $71-80$ 
$314 \mathrm{~mm}$ from the 2015 Portsmouth (30.43\%), 2015 Chichester (30.43\%) and 2016 Langstone (37\%)

315 populations and $61-70 \mathrm{~mm}$ in the 2017 Langstone \& Chichester (43.85\%) combined population.

316 The demographic structure is narrower within the 2016 and 2017 populations sampled (Fig. 5).

317 The NORMSEP modal progression analysis used to identify the number of cohorts, or age

318 classes from the size frequency data confirmed the narrowing demographic structure and lack of

319 recruitment cohorts (Table 2). The number and distribution of the cohorts suggest low levels of

320 recent recruitment across all harbours and years. Three modes were estimated from the

321 Portsmouth size class frequency data but dominated $(\mathrm{n}=652)$ by the smallest cohort with an

322 estimated mean of $84.57 \pm 9.67 \mathrm{~mm}$ (modal mean $\pm \mathrm{SD}$ ) with a tail of low frequency larger size

323 classes, effectively suggesting a single aged cohort. Three more evenly distributed modes were

324 identified in the 2015 Chichester population with a smaller cohort of $71.73 \mathrm{~mm}(\mathrm{n}=559)$. The

325 temporal trend demonstrates a decreasing population structure. Only two cohorts were identified

326 in both the 2016 Langstone and 2017 Langstone \& Chichester populations, the latter dominated

327 almost entirely by a single cohort $(\mathrm{n}=743 / 757)$ of $71.20 \pm 8.78 \mathrm{~mm}$. (modal mean \pm SD).

328

329

330

331

332

333

334

335

336

337

\section{Condition index (CI) and prevalence of Bonamia ostreae:}

There was no significant difference between the condition index of the Chichester, 3.3

$\pm 0.5 \mathrm{~g}$ dry wt (mean $\pm \mathrm{SE}$ ), and Portsmouth populations, $3.97 \pm 0.5 \mathrm{~g}$ dry wt (mean $\pm \mathrm{SE}),\left(F_{1,46}=\right.$ $0.9, P \geq 0.05)$. The PCR provided 91 positive amplifications of the $\mathrm{Oe}$ fw_1 / Oe rev_4 positive control. Those that did not provide positive amplifications were discarded from the results.

Those that provided positive amplifications showed that $46.8 \%$ of the Chichester oysters and $80 \%$ of the Portsmouth oysters, were not infected with microcell Haplosporidians or Bonamia ostreae. The remaining 53.2\% of oysters from Chichester were infected, $32 \%$ tested positive for a microcell Haplosporidian other than B. ostreae and $21.2 \%$ positive for B. ostreae. In 
338 comparison to this, $20 \%$ of the Portsmouth oysters that were infected showed only positive

339 amplifications for microcell Haplosporidians other than B. ostreae, with no evidence of $B$.

340 ostreae found.

341 Incidences of bonamiosis within the Chichester population occurred across a range of different

342 sized oysters. However, the majority (66.7\%) occurred in oysters $<82 \mathrm{~mm}$ in length, all with a

343 dry tissue weight of $<2 \mathrm{~g}$. Incidence of infection with microcell Haplosporidians, other than $B$.

344 ostreae, within the Chichester population occurred in oysters $<87 \mathrm{~mm}$ in length, all with a dry

345 tissue weight of $<4 \mathrm{~g}$. In comparison, the incidence of infection with microcell Haplosporidians,

346 other than B. ostreae, within the Portsmouth population occurred in oysters between $70-100$

$347 \mathrm{~mm}$ in length, with dry tissue weights between 2 and $11 \mathrm{~g}$. No relationship was observed

348 between condition index, maximum shell length and infection with $B$. ostreae $\left(F_{2,21}=0.6, P \geq\right.$ $3490.05)$.

350 A small proportion (4.1\%) of the sample population from Langstone Harbour showed

351 positive products and were sequenced, showing 100\% homology to B. ostreae (KY296102.1)

352 with those infected showing light to moderate levels.

353

354

355

356

357

358

359

360

361

\section{Densities of Ostrea edulis and Crepidula fornicata in 2017}

During the survey, no oysters were found in Portsmouth Harbour, two were found in Langstone Harbour and one found in Chichester Harbour. (Fig. 6A).

In contrast, $C$. fornicata was abundant in many areas, with mean harbour densities of 84.1

$\pm 24.5,174.3 \pm 34.5$ and $306 \pm 106$ limpets $/ \mathrm{m}^{2}$ (mean $\pm \mathrm{SE}$ ) for Portsmouth, Langstone and

Chichester, respectively (Fig. 6B). Both Langstone and Chichester Harbours contained

significantly more individuals than Portsmouth Harbour. Even though Chichester contained more 
362 limpets $/ \mathrm{m}^{2}$ than Langstone, no significant difference was found $\left(F_{2,273}=4.1, P \geq 0.05\right)$.

363 Significantly more $C$. fornicata were found across all three harbours compared with Ostrea

364 edulis $(\mathrm{t}$-value $=4.9, P \leq 0.001)$.

365

366

Densities of Ostrea edulis and Crepidula fornicata in Chichester Harbour in 1998

367

In 1998 O. edulis was present in many areas of Chichester Harbour, with 14 out of 29

368

sites having oysters, the sites provided mean densities ranging from 0 to 88 oysters $/ \mathrm{m}^{2}$ and the

369

overall harbour density was $8.0 \pm 2.7$ oysters $/ \mathrm{m}^{2}$ (mean $\pm \mathrm{SE}$ ) (Fig. 7A). Crepidula fornicata

370

was present in 19 of the 29 sites within the harbour. Mean densities per sample site ranged from

371

0 to 1224 limpets $/ \mathrm{m}^{2}$ and the overall harbour density was $181.2 \pm 40.7$ limpets $/ \mathrm{m}^{2}$ (mean $\pm \mathrm{SE}$ )

372

(Fig. 7B). There were significantly more $C$. fornicata than $O$. edulis (t-value $=4.9, P \leq 0.001$ ).

373

374

375

376

\section{Long term data comparison of $O$ strea edulis and Crepidula fornicata densities}

In Chichester Harbour a significant decrease in O. edulis density was observed between

1998 and 2017 , from $8.0 \pm 2.7$ to $0.1 \pm 0.1$ oysters $/ \mathrm{m}^{2}($ mean $\pm \mathrm{SE})\left(F_{1,172}=19.3, P \leq 0.001\right)$ (Fig.

7C). In comparison, a significant increase was observed for C. fornicata between 1998 and 2017,

from $181.2 \pm 40.7$ to $306 \pm 106$ limpets $/ \mathrm{m}^{2}$ (mean $\left.\pm \mathrm{SE}\right)\left(F_{1,142}=10.4, P \leq 0.01\right)$ (Fig. $\left.7 \mathrm{D}\right)$.

\section{DISCUSSION}

In addition to the comprehensive stock assessment conducted by the Southern IFCA

(Southern IFCA 2017) the data presented here are essential for determining the relative

distribution and benthic composition of oysters and slipper limpets to provide a baseline status of 
386 also used to determine the future success of restoration activities proposed the Solent (e.g.

387 Harding et al. 2016). The narrowing of fishery landing sizes combined with the significant

388 decrease in the abundance of the ecosystem engineer, Ostrea edulis, within Chichester,

389 Langstone and Portsmouth Harbours indicated that these populations of native oysters are not

390 recovering, recruiting or present in reproductively relevant densities.

391 The long-term decline of $O$. edulis standing stock is caused by a combination of chronic

392 overfishing, poor water quality (Environment Agency 2016) and disease, which suggests a loss

393 of the ecosystem services that biogenic oyster habitats are able to provide. As demonstrated by

394 studies of various oyster species, such a loss will likely have a profound negative impact on

395 biodiversity, benthic community structure, trophic pathways and water quality across the Solent

396 as it is highly probable that oysters and oyster reefs are universal in terms of ecosystem services

397 provision (Lenihan 1999, Jackson et al. 2001, Peterson et al. 2003, Tolley \& Volety 2005, Smyth

$398 \&$ Roberts 2010). The continued expansion of the invasive, non-native and highly successful

399 gastropod, Crepidula fornicata, has been facilitated by the decline in oysters, impoverished

400 habitat, global shipping movements and a prolific lifecycle (Richard et al. 2006). The presence of

401 such high densities highlights the impoverished state of the habitat, now a silty mud-dominated

402 benthos which presents a barrier to the restoration of oyster-related benefits that previously once

403 existed (Korringa 1946, Barnes et al. 1973, Erhold et al. 1998, Thouzeau et al. 2003, Streftaris \& 404 Zenetos 2006).

405 First sighted in oyster ponds in Bosham, 'Portsmouth Bay', during 1913 (Cole 1952), and

406 later in the wider Solent in 1930, C. fornicata spread west during the 1940s (Blanchard, 1997).

407 By the 1970s the Solent was almost characterised by C. fornicata dominated associated

408 macrofauna. However, O. edulis still occurred with a 19\% frequency, but greater in the West 
$409(45 \%)$ than the East Solent (9\%), (Barnes et al 1973). This persistent and increasing dominance

410 of C. fornicata since the 1970 s is of serious concern for the natural recovery of O. edulis,

411 particularly the extremely high densities of over $4000 \mathrm{~m}^{2}$ within Chichester Harbour which

412 demonstrates the ecological carrying capacity of inshore waters for this invasive species. The

413 extent to which $C$. fornicata, at high densities, competitively excludes $O$. edulis should be tested.

414 The presence of $C$. fornicata not only negatively impacts the broodstock oyster

415 population but $O$. edulis larvae could also be subject to substantial predation (Korringa 1951 in

416 Pechenik et al. 2004) and competition. Oyster larvae attempting to settle will suffer competition

417 for food and space from high C. fornicata larval densities (Fitzgerald, 2007) which form a

418 cohesive calcareous shell-mud where they become dominant in contrast to hard substrate

419 preferred by oyster larvae (Smyth et al 2018). The reduced availability of suitable settlement

420 substrate for O. edulis larvae due to both the levels of mucus pseudofaeces (Blanchard 1997)

421 generated by such high densities of $C$. fornicata and the lack of conspecific shell substrate is a

422 major concern. A reduction in preferential substrata will be further compounded by competition

423 for food arising during the overlapping breeding periods of both species, with C. fornicata

424 spawning two to four times between February and September (Richard et al. 2006) and O. edulis

425 typically spawning once between May and August (Hayward et al. 1996). The reproductive cycle

426 of $O$. edulis is also relatively complex in relation to other oyster species and that of C. fornicata

427 which is sexually mature within 2 months (Richard et al. 2006). In comparison, O. edulis is not

428 usually mature until individuals reach 3 years old (Roberts et al. 2010).

429 Again this is problematic as the remaining natural populations of mature oysters, within

430 the sampled harbours of the Solent, have decreased significantly in size and abundance over a

431 short time frame. This smaller, less mature and narrowed demographic population will 
432 negatively impact spawning potential. For example, a decrease in mean size from $80 \mathrm{~mm}$ to 70

$433 \mathrm{~mm}$, similar to the decline observed from $2015-2017$, would result in a reduced output of

434260,000 larvae per reproductive female (Walne 1974). When applied to a fishery, characterised

435 by a skewed sex ratio (6:1 male:female sex ratio (Kamphausen et al. 2011)), reproductive and

436 recruitment success will be severely impacted. This is of great concern and as a conservative

437 estimate, $85 \%$ of the 2017 Langstone \& Chichester population will be above the minimum

438 landing size for the 2018/19 fishing season and therefore at high risk of being extracted to the

439 point of functional extinction (Beck et al. 2011). To put this in context, in 1973 only $22 \%$ of $O$.

440 edulis population in Stanswood Bay were of marketable size $>70 \mathrm{~mm}$ (Barnes et al, 1973), and it

441 was this population that was thought to feed the boom of the Solent fishery in the late 1970s and

4421980 s.

This risk of extirpation at current fishing levels seems particularly high as there is little or

444 no sign of recruitment cohorts for the sampled harbours. The last successful recruitment,

445 estimated from size (Richardson et al. 1993), was approximately 5 - 6 years ago in 2012 for the

446 Langstone \& Chichester Populations. The smallest 2015 Portsmouth cohort with a mean

447 maximum length of $84 \mathrm{~mm}$ suggests this is the aged remnant population from a successful

448 spatfall 8 - 10 years ago, approximately in 2008. The morphometric data reveals a disjunct

449 population structure over microgeographic scales within the Solent, particularly between the

450 Portsmouth and Chichester Harbours in 2015. This could be attributed to the re-stocking that

451 took place as part of a small-scale restoration project in Chichester during November 2010

452 (Vause 2010, Eagling 2012 cited in Gravestock et al. 2014, MEDIN 2016), which aligns with the

453 estimate from the demographic cohorts. However, it is concerning that the demographic data 
454 showed a lack of recruitment to the seabed in all three harbours despite the previous two years of

455 fishery closure and a reduced fishing season since 2015.

456

When planning and managing projects to restore such populations, disease control is of

457 utmost importance. The prevalence of Bonamia ostreae within the Chichester population in this

458 study has increased from previous years (1993 - 2007 average 12.1\% (Laing et al. 2014)) and are

459 in agreement with the findings of Eagling (2012, cited in Gravestock et al. 2014), who reported

460 disease prevalence of $25-35 \%$. This increase could be attributable to the mortality of many of

461 the re-laid oysters (at a density of $20 / \mathrm{m}^{2}$ ) within the harbour observed by Jensen (pers. comm.

462 with Gravestock et al. 2014) and indicate that this area may be susceptible to future outbreaks of

463 Bonamiosis.

464 In contrast to this, the parasite was completely absent within the Portsmouth population

465 decreasing from an average of 5.6\% (1993 - 2007 (Laing et al. 2014)). This result is encouraging

466 with the apparent absence of $B$. ostreae from a population previously exposed and subject to the

467 parasite and could be indicative of resistance. Again, in contrast to the increase within

468 Chichester, a reduction in prevalence was recorded within the Langstone population (9.1\% mean

4691993 - 2007 (Laing et al. 2014)). This suggests that although the three harbours are all

470 interconnected the hydrodynamics of the area appear to prevent dispersal of the parasite in a

471 westerly direction either in the water column or via larval transmission (Flannery et al. 2016) and

472 is supported by the distinct demographic structure of the Portsmouth population, however, given

473 the exceptionally low population densities this could be a density dependent phenomenon.

474 It is clear that the C. fornicata dominated benthos of the Solent harbours is in a poor state

475 and without significant intervention or disturbance, presents a barrier to the return of the native

476 oyster $O$. edulis along with the biogenic habitat and associated biodiversity it provides. 
478

479

480

481

482

483

484

485

486

487

488

489

490

491

492

493

494

495

496

497

498

499

500

501

502

503

504

505

506

\section{CONCLUSION}

The low standing stock of Ostrea edulis, coupled with a benthos dominated by high densities of Crepidula fornicata, and the presence of Bonamia ostreae and continued fishing pressure are significant barriers to self-sustaining native oyster populations within the Solent. Based on the status of $O$. edulis in the commercially fished areas of the Solent presented here, active management of the seabed is recommended to 1) control the extent and spread of

Crepidula fornicata, 2) provide suitable settlement substrate for $O$. edulis larval recruitment and 3) establish a protected $O$. edulis broodstock population in all commercially fished Solent harbours, in agreement with Fariñas-Franco et al. (2018).

This paper highlights the importance of understanding local population structures and disease prevalence over relatively small geographic scales and reinforces the need for relevant and comprehensive baseline data to underpin $O$. edulis restoration practices. All the results highlight the impoverished state of the native oyster, in what was once a substantial population, thus the need to restore the species to the area.

\section{REFERENCES}

Anon (1912-1940) Annual Report on Sea Fisheries, England and Wales, 19010-1938. Her Majesty's Stationary Office, London. (Reports for the years 1910-1918 were issues by the Board of Agriculture and Fisheries: Reports for the years 1919-1938 were issued by the Ministry of Agriculture and Fisheries).

Barnes RSK, Goughlan J, Holmes NJ (1973) A preliminary survey of the macro-scopic bottom fauna of the Solent, with particular reference to Crepidula fornicata and Ostrea edulis. Journal of Molluscan Studies 40: 253-275.

Baud JP, Gerard A, Naciri-Greven Y (1997) Comparative growth and mortality of Bonamia ostrae-resistan and wild flat oysters, Ostrea edulis, in an intensive system. I. First year of experiment. Marine Biology 130: 71-79.

Beck MW, Brumbaugh RD, Airoldi L, Carranza A, Coen LD, Crawford C, Defeo O, Edgar GJ, Hancock B, Kay MC, Lenihan HS, Luckenbach MW, Toropova CL, Zhang G, Guo X 
507

(2011) Oyster Reefs at Risk and Recommendations for Conservation, Restoration, and Management. Bioscience 61: 107-116.

Bell SS, McCoy ED, Mushinsky HR (1991) Habitat structure: the physical arrangement of objects in space. Chapman \& Hall, London, UK.

Blanchard M (1997) Spread of the slipper limpet Crepidula fornicata (L. 1758) in Europe. Current state and consequences. Scientia Marina 61: 109-118.

Blanchard M (2009) Recent expansion of the slipper limpet population (Crepidula fornicata) in the Bay of Mont-Saint-Michel (Western Channel, France). Aquatic Living Resources 22: $11-19$.

Carbines G, Jiang W, Beentjes MP (2004) The impact of oyster dredging on the growth of blue cod, Parapercis colias, in Foveaux Strait, New Zealand. Aquatic Conservation 14: 491-504.

Carnegie RB, Barber BJ, Culloty SC, Figueras AJ, Distel DL (2000) Development of a PCR assay for detection of the oyster pathogen Bonamia ostreae and support for its inclusion in the Haplosporidia. Diseases of Aquatic Organisms 42: 199-206.

Chipperfield PNJ (1951) The breeding of Crepidula fornicata (L.) in the river Blackwater, Essex. Journal of the Marine Biological Association of the UK 30: 49-71.

Cigarria J, Fernandez JM, Lopez-Basanez MJ (1995) Viability on the culture of flat oyster (Ostrea edulis L.) in the EO Estuary (Asturias, N Spain). Iberus 13: 1-8.

Cochennec N, Roux F Le, Berthe F, Gerard A (2000) Detection of Bonamia ostreae Based on Small Subunit Ribosomal Probe. Journal of Invertebrate Pathology 76: 26-32.

Coen LD, Brumbaugh RD, Bushek D, Grizzle R, Luckenbach MW, Posey MH, Powers SP, Tolley SG (2007) Ecosystem services related to oyster restoration. Marine Ecology Progress Series 341: 303-307.

Coen LD, Luckenbach MW, Breitburg DL (1999) The role of oyster reefs as essential fish habitat: a review of current knowledge and some new perspectives. American Fisheries Society Symposium 22: 438-454.

Cole HA (1952). The American slipper limpet (Crepidula fornicata) on Cornish beds. Fish. Invest., ser. 2, 17(7): 1-13.

Cole HA, Baird RH (1953) The American slipper limpet (Crepidula fornicata) in Milford Haven. Nature 172: 687-687.

Cole W (1915) The abundance of the slipper limpet (Crepidula) in the Essex waters. Essex Naturalist 18: 81-82.

Cranfield HJ, Michael KP, Doonan IJ (1999) Changes in the distribution of epifaunal reefs and oysters during 130 years of dredging for oysters in Foveaux Strait, southern New Zealand. Aquatic Conservation: Marine and Freshwater Ecosystems 9: 461-483.

Christianen MJA, Lengkeek W, BergsmaJH, Coolen JWP, Didderen K, Dorenbosch M, Driessen FMF, Kamermans P, Reuchlin-Hugenholtz E, Sas H, Smaal A, van den Wijngaard KA, van der Have (2018) Return of the native facilitated by the invasive? Population composition, substrate preferences and epibenthic species richness of a recently discovered shellfish reef with native European flat oysters (Ostrea edulis) in the North Sea. Marine Biology Research, 14(6): 590-597.

Crouch W (1893) On the occurrence of Crepidula fornicata in Essex. Proceedings of the Malacological Society London 1: pp 19.

Culloty SC, Cronin MA, Mulcahy MF (2001) An investigation into the relative resistance of Irish flat oysters Ostrea edulis L. to the parasite Bonamia ostreae. Aquaculture 199: 229244. 
553

554

555

556

557

558

559

560

561

562

563

564

565

566

567

568

569

570

571

572

573

574

575

576

577

578

579

580

581

582

583

584

585

586

587

588

589

590

591

592

593

594

595

596

597

Culloty SC, Cronin M, Mulcahy MF (2004) Potential resistance of a number of populations of the oyster Ostrea edulis to the parasite Bonamia ostreae. Aquaculture 237: 41-58.

Culloty SC, Mulcahy MF (2007) Bonamia ostreae in the native oyster Ostrea edulis: a review. Marine Environment and Health Series No. 29: 1-36.

Davidson P (1976) Oyster Fisheries of England and Wales. Technical Report. Ministry of Agriculture Fisheries and Food, Directorate of Fisheries Research, Fisheries Laboratory Lowestoft, Suffolk. pp 19.

Davis MA, Thompson K (2000) Eight Ways to be a Colonizer; Two Ways to be an Invader: A proposed nomenclature scheme for invasion ecology. Bulletin of the Ecological Society of America 81: 226-230.

de Montaudouin X, Sauriau PG (1999) The proliferating Gastropoda Crepidula fornicata may stimulate macrozoobenthic diversity. Journal of the Marine Biological Association of the UK 79: 1069-1077.

Dodd SB (1893) Note on the possibility of the acclimatization of Crepidula fornicata in the British Seas. Proceedings of the Malacological Society London 1:31-32.

Eagling L (2012) Reproductive success of the re-laid native oyster Ostrea edulis in Chichester Harbour. MSci Thesis. University of Southampton, UK.

Edwards E (1997) Molluscan fisheries in Britain. NOAA Technical report Nmfs 129: 85-100.

Environment Agency (2016) Datasheet: Nitrate vulnerable zone (NVZ) designation 2017 Eutrophic Waters (Estuaries and Coastal Waters). NVZ: Portsmouth Harbour, Langstone Harbour and Chichester Harbour. NVZ ID: ET2. Available at http://apps.environmentagency.gov.uk/static/documents/nvz/NVZ2017_ET2_Chichester_Langstone_Portsmouth_D atasheet.pdf. Last accessed 09 February 2018.

Erhold A, Blanchard M, Auffret JP, Garlan T (1998) Conséquences de la prolifération de la crépidule, Crepidula fornicata sur l'évolution sédimentaire de la baie du Mont SaintMichel, Manche, France. Comptes Rendus de l'Académie des Sciences - Series IIA - Earth and Planetary Science 327: 583-588

Fariñas-Franco JM, Pearce B, Mair JM, Harries DB, MacPherson RC, Porter JS, Reimer PJ, Sanderson WG (2018). Missing native oyster (Ostrea edulis L.) beds in a European Marine Protected Area: Should there be widespread restorative management? Biological Conservation, 221, 293-311.

Farrell P (1998) Survey of the Molluscan Shellfish in Chichester Harbour. Chichester Harbour Conservancy Research report 85. http://www.conservancy.co.uk/library/view/85/

Figueras A (1991) Bonamia status and its effects in cultured flat oysters in the Ria de Vigo, Galicia (NW Spain). Aquaculture 93: 225-233.

Flannery G, Lynch SA, Culloty SC (2016) Investigating the significance of the role of Ostrea edulis larvae in the transmission and transfer of Bonamia ostreae. Journal of Invertebrate Pathology 136: 7-9.

Gardner J, Elliott M (2001) UK Biodiversity Action Plan Native Oyster Species Information Review. Technical report. Institute of Estuarine and Coastal Studies, University of Hull, No. Z123-F-2001 Report to English Nature. pp 178.

Gercken J, Schmidt A (2014) Current Status of the European Oyster (Ostrea edulis) and Possibilities for Restoration in the German North Sea. Retrieved from: https://www.bfn.de/fileadmin/BfN/meeresundkuestenschutz/Dokumente/2015-0602_Auster_Machbarkeitsstudie-barrierefrei-english.pdf 
598

599

600

601

602

603

604

605

606

607

608

609

610

611

612

613

614

615

616

617

618

619

620

621

622

623

624

625

626

627

628

629

630

631

632

633

634

635

636

637

638

639

640

641

642

643

Goulletquer P, Heral M (1997) Marine molluscan production trends in France: from fisheries to aquaculture. NOAA Tech. Rep. NMFS 129: 137-164.

Grabowski JH, Brumbaugh RD, Conrad RF, Andrew G, Opaluch JJ, Peterson CH, Piehler MF, Powers SP, Smyth R, Grabowski JH, Brumbaugh RD, Conrad RF, Keeler AG, James J (2012) Economic Valuation of Ecosystem Services Provided by Oyster Reefs. BioScience 62: 900-909.

Gravestock V, James F, Goulden M (2014) Solent Native Oyster (Ostrea edulis) Restoration Literature Review \& Feasibility Study. Conducted on behalf of the Blue Marine Foundation.

Gross F, Smyth JC (1946) The Decline of Oyster Populations. Nature 157 (3991):540-541

Grizel H (1985) Study of the recent epizooties of the flat oyster Ostrea edulis Linné and their impact on Breton oyster culture. PhD thesis, Université des Sciences et Techniques de Languedoc, Montpellier, France.

Grizel H, Mialhe E, Chagot D, Boulo V, Bachere E (1988) Bonamiasis: A Model Study of Diseases in Marine Molluscs. American Fisheries Society Special Publication Series 18: 14.

Grizzle RE, Greene JK, Coen LD (2008) Seston Removal by Natural and Constructed Intertidal Eastern Oyster (Crassostrea virginica) Reefs: A Comparison with Previous Laboratory Studies, and the Value of in situ Methods. Estuaries and Coasts 31: 1208-1220.

Gruet Y, Prigent D (1986) Les buttes de St Michel en L'Herm (Vendee): caractères de la population d'huitres Ostrea edulis L. et sa faune associee. [Oyster shell piles in St. Michel en L'Herm (Vendee): characteristics of the flat oyster Ostrea edulis population and the associated fauna.]. Haliotis 15: 3-16.

Gunther RT (1897) The oyster culture of the ancient Romans. Culture 4: 360-365.

Gutiérrez-Zugasti I, Andersen SH, Araújo AC, Dupont C, Milner N, Monge-Soares Antonio M. AM (2011) Shell midden research in Atlantic Europe: State of the art, research problems and perspectives for the future. Quaternary International 239: 70-85.

Harding JM, Mann R (2001) Oyster reefs as fish habitat: opportunistic use of restored reefs by transient fishes. Journal of Shellfish Research 20: 951-959.

Harding S, Nelson L, Glover T (2016) Blue Marine Foundation Solent Oyster Restoration Project Management Plan. http://www.bluemarinefoundation.com/wpcontent/uploads/2016/06/20160525_Solent $\% 200$ yster\%20Restoration\%20Project_Management\%20Plan_Final\%20version.pdf

Hawkins LE, Hutchinson S, Askew C (2005) Evaluation of some factors affecting native oyster stock regeneration. Shellfish News 19: 10-12.

Hayward P, Nelson-Smith T, Shields C (1996) Collins Pocket Guide: Sea Shore of Britain and Europe. London: HarperCollins Publishers.

Hoagland KE (1985) Genetic-Relationships Between One British and Several North-American Populations of Crepidula fornicata Based On Allozyme Studies (Gastropoda, Calyptraeidae). Journal of Molluscan Studies 51: 177-182.

Humphries AT, La Peyre MK (2015) Oyster reef restoration supports increased nekton biomass and potential commercial fishery value. PeerJ 3: e1111.

Jackson JBC, Kirby MX, Berger WH, Bjorndal KA, Botsford LW, Bourque BJ, Bradbury RH, Cooke R, Erlandson J, Estes JA, Hughes TP, Kidwell S, Lange CB, Lenihan HS, Pandolfi JM, Peterson CH, Steneck RS, Tegner MJ, Warner RR (2001) Historical overfishing and the collapse of coastal ecosystems. Science 293: 629-637. 
644 Kamphausen LM (2012) The reproductive processes of a wild population of the European flat

645

646

647

648

649

650

651

652

653

654

655

656

657

658

659

660

661

662

663

664

665

666

667

668

669

670

671

672

673

674

675

676

677

678

679

680

681

682

683

684

685

686

687

688

689 oyster Ostrea edulis in the Solent, UK. PhD: pp 154.

Kamphausen L, Jensen A, Hawkins L (2011) Unusually High Proportion of Males in a Collapsing Population of Commercially Fished Oysters (Ostrea edulis) in the Solent, United Kingdom. Journal of Shellfish Research 30: 217-222.

Kellogg ML, Cornwell JC, Owens MS, Paynter KT (2013) Denitrification and nutrient assimilation on a restored oyster reef. Marine Ecology Progress Series 480 (2013): 1-19.

Key D, Davidson PE (1981) A review of the development of the Solent oyster fishery 1972-80. Ministry of Agriculture, Fisheries and Food, Directorate of Fisheries Research. Lab Leaflet No 52: pp 40

Korringa P (1946). The decline of natural oyster beds. Basteria, 10(3/4), 36-41.

Korringa P (1951) Crepidula fornicata as an oyster-pest. Conseil Permanent International Pour l'exploration de la Mer. 128: 55-59.

Laing I, Dunn P, Peeler EJ, Feist SW, Longshaw M (2014) Epidemiology of Bonamia in the UK, 1982 to 2012. Diseases of Aquatic Organisms 110: 101-111.

Laing I, Walker P, Areal F (2005) A feasibility study of native oyster (Ostrea edulis) stock regeneration in the United Kingdom: CEFAS pp 97.

Laing I, Walker P, Areal F (2006) Return of the native - is European oyster (Ostrea edulis) stock restoration in the UK feasible? Aquatic Living Resources. 19: 283-287.

Lallias D, Arzul I, Heurtebise S, Ferrand S, Chollet B, Robert M, Beaumont AR, Boudry P, Morga B, Lapègue S (2008) Bonamia ostreae - induced mortalities in one-year old European flat oysters Ostrea edulis: experimental infection by cohabitation challenge. Aquatic Living

Resources. 439: 423-439.

Lallias D, Boudry P, Lapègue S, King J (2010) Strategies for the retention of high genetic variability in European flat oyster (Ostrea edulis) restoration programmes. Conservation Genetics 11: 1899-1910.

Lallias D, Gomez-Raya L, Haley CS, Arzul I, Heurtebise S, Beaumont AR, Boudry P, Lapègue S (2009) Combining two-stage testing and interval mapping strategies to detect QTL for resistance to Bonamiosis in the European flat oyster Ostrea edulis. Marine Biotechnology 11: $570-584$.

Lenihan HS (1999) Physical-Biological Coupling on Oyster Reefs: How Habitat Structure Influences Individual Performance. Ecological Monographs 69: 251-275.

Le Pape O, Guerault D, DesaunayY (2004) Effect of an invasive mollusc, American slipper limpet Crepidula fornicata, on habitat suitability for juvenile common sole Solea solea in the Bay of Biscay. Marine Ecology Progress Series. 277: 107-115.

Lucas A, Beninger PG (1985) The use of physiological condition indices in marine bivalve aquaculture. Aquaculture 44: 187 - 220.

Lynch SA, Armitage D V, Wylde S, Mulcahy MF, Culloty SC (2005) The susceptibility of young prespawning oysters, Ostrea Edulis, to Bonamia ostreae. J Shellfish Res 24: 10191025.

MacKenzie CLJ, Burrell VGJ, Rosenfield A, Hobart WL (1997) The history, present condition, and future of the molluscan fisheries of North and Central America and Europe. Volume 1, Atlantic and Gulf coasts. NOAA Tech Rep NMFS, 127: 223-234.

McMillan NF (1938) Early records of Crepidula in English waters. J Molluscan Stud 23: 236. MEDIN - Marine environmental data \& information network (2016) Metadata: 2010 onwards Chichester Harbour Native Oyster, Ostrea edulis population monitoring. Retrieved from: 
690

691

692

693

694

695

696

697

698

699

700

701

702

703

704

705

706

707

708

709

710

711

712

713

714

715

716

717

718

719

720

721

722

723

724

725

726

727

728

729

730

731

732

733

734

735

http://portal.oceannet.org/search/full/catalogue/dassh.ac.uk_MEDIN_2.3_62f64310cee87 07d9f9d5e82e266edfd.xml

Minchin D, McGrath D, Duggan CB (1995) The slipper limpet, Crepidula fornicata (L.), in Irish waters, with a review of its occurrence in the north-eastern Atlantic. Journal of Conchology 35: 249-256.

Moore TJ (1880) "Note on the possible naturalization of the American Clam Venus mercenaria, on the Coasts of Lancashire and Cheshire," First rep. Fauna Liverpool Bay, pp 308-370.

OIE (2003). Manual of Diagnostic Tests for Aquatic Animals. 4th edition. Office International des Epizooties: pp 230-234.

Orton JH (1950) The recent extension in the distribution of the American slipper limpet, Crepidula fornicata, into Lyme Bay in the English Channel. J Mollusc Stud 28: 168-184.

Pechenik JA, Blanchard M, Rotjan R (2004) Susceptibility of larval Crepidula fornicata to predation by suspension-feeding adults. Journal of Experimental Marine Biology and Ecology 306: 75-94.

Perry F, Jackson A (2017) Ostrea edulis Native oyster. In Tyler-Walters H. and Hiscock K. (eds) Marine Life Information Network: Biology and Sensitivity Key Information Reviews. Plymouth: Marine Biological Association of the United Kingdom. Available from: https://www.marlin.ac.uk/species/detail/1146. Last accessed 08 January 2018.

Peterson CH, Grabowski JH, Powers SP (2003) Estimated enhancement of fish production resulting from restoring oyster reef habitat: Quantitative valuation. Marine Ecology Progress Series 264: 249-264.

Philpots R (1890) Oysters and all about them. John Richardson, London. pp 241.

Piehler MF, Smyth AR (2011) Habitat-specific distinctions in estuarine denitrification affect both ecosystem function and services. Ecosphere 2: 1-17.

Richard J, Huet M, Thouzeau G, Paulet Y-M (2006) Reproduction of the invasive slipper limpet, Crepidula fornicata, in the Bay of Brest, France. Marine Biology 149: 789-801.

Richardson CA, Collis SA, Ekaratne K, Dare P, Key D (1993) The age determination and growth rate of the European flat oyster, Ostrea edulis, in British waters determined from acetate peels of umbo growth lines. ICES Journal of Marine Science. https://doi.org/10.1006/jmsc.1993.1052

Roberts C, Smith CHT, Tyler-Walters H (2010) Review of existing approaches to evaluate marine habitat vulnerability to commercial fishing activities. Report to the Environment Agency from the Marine Life Information Network and ABP Marine Environmental Research Ltd. Environment Agency Evidence Report: SC080016/R3., Environment Agency, Peterborough, pp. http://publications.environmentagency.gov.uk/PDF/SCHO1110BTEQ-E-E.pdf

Roberts D, Smyth D, Browne L (2005) Native oyster (Ostrea edulis) fishery enhancement in Strangford Lough, Northern Ireland. Shellfish News 20: 5-6.

Shelmerdine RL, Leslie B (2009) Restocking of the native oyster, Ostrea edulis, in Shetland: habitat identification study. Scottish Natural Heritage Commissioned Report No. 396.

Smyth AR, Geraldi NR, Piehler MF (2013) Oyster-mediated benthic-pelagic coupling modifies nitrogen pools and processes. Marine Ecology Progress Series 493: 23-30.

Smyth D, Roberts D (2010) The European oyster (Ostrea edulis) and its epibiotic succession. Hydrobiologia 655: 25-36.

Smyth D, Mahon AM, Roberts D, Kregting L (2018) Settlement of Ostrea edulis is determined by the availability of hard substrata rather than by its nature: Implications for stock recovery 
736

752

753

754

755

756

757

758

759

760

761

762

763

764

765

766

767

768

769

770

771

772

773

774

775

776

777

778

779

and restoration of the European oyster. Aquatic Conservation: Marine and Freshwater Ecosystems, (September 2016), 662-671. https://doi.org/10.1002/aqc.2876

Southern Inshore Fisheries and Conservation Authority (2018) Byelaws - Oyster Dredges, Temporary Closure of Shellfish Beds, Oyster Close Season. Available at: http://www.southern-ifca.gov.uk/byelaws\#Oyster-Dredges. Last accessed 09 February 2018.

Streftaris N, Zenetos A (2006) Alien marine species in the Mediterranean - the 100 "worst invasives" and their impact. Mediterranean Marine Science 7: 87-118.

Sussex Inshore Fisheries and Conservation Authority (2018) Oyster permit - Oyster Permit Byelaw, Oyster Permit Byelaw conditions, Application form, Guidance for permit holders. Available at: http://www.sussex-ifca.gov.uk/oyster-permit. Last accessed 09 February 2018. Thieltges DW (2005) Impact of an invader: epizootic American slipper limpet Crepidula fornicata reduces survival and growth in European mussels. Marine Ecology Progress Series 286: 13-19.

Thieltges DW, Strasser M, Reise K (2003) The American slipper limpet Crepidula fornicata (L.) in the northern Wadden Sea 70 years after its introduction. Helgoland Marine Research. 57: 2733.

Thouzeau G, Chauvaud L, Durand G, Patris T, Glemarec M (2003) Impact des polluants d'origine anthropique sur les organismes benthiques marins: notions d'indicateurs biologiques de perturbation et de réseaux de surveillance. Institut Océanographique 27: 177-214.

Tolley SG, Volety A (2005) The role of oysters in habitat use of oyster reefs by resident fishes and decapod crustaceans. Journal of Shellfish Research 24: 1007-1012.

Tubbs C (1999) The ecology, conservation and history of the Solent. Packard Publishing Limited, Chichester.

UKBAP (1999) Tranche 2 Action plans. Maritime species and Habitats. Retrieved from: http://jncc.defra.gov.uk/PDF/UKBAP_Tranche2-ActionPlans-Vol5-1999.pdf

Utting SD, Spencer BE (1992) III. Shellfish Introductions of marine bivalve molluscs into the United Kingdom for commercial culture -case histories Case histories of introductions. ICES Marine Science Symposia 194: 84-91.

Vallet C, Dauvin J, Hamon D, Dupuy C, Vallet C, Dauvin J, Hamon D, Dupuy C (2001) Effect of the Introduced Common Slipper Shell on the Suprabenthic Biodiversity of the Subtidal Communities in the Bay of Saint-Brieuc. Conservation Biology 15: 1686-1690.

Vanstaen K, Palmer D (2009) Solent Regulated Fishery Oyster Stock Survey 16 - 22 June 2009. Technical report. Centre for Environment, Fisheries and Aquaculture Science, Lowestoft Laboratory. pp 29.

Vause B (2010) Chichester Harbour Oyster Initiative. Shellfish News 30: 5-6.

Walne PR (1974) Culture of Bivalve Molluscs: 50 years' experience at Conwy (2nd ed.). Fishing News [for the Buckland Foundation], West Byfleet.

Walne PR, Mann R (1975) Growth and biochemical composition in Ostrea edulis and Crassostrea gigas. In: Barnes, H. (Ed.), Proceedings of the 9th European Marine Biology Symposium. Aberdeen Univ. Press, Aberdeen, pp. 587 - 607.

Wells HW (1961) The Fauna of Oyster Beds, with Special Reference to the Salinity Factor Ecological Monographs. 31 (3): 239-266. 
780 Woolmer AP, Syvret M, Fitzgerald A (2011) Restoration of Native Oyster, Ostrea edulis, in South Wales: Options and Approaches. Countryside council for Wales. CCW Contract Science Report, 960.

Zimmerman R, Minello T, Baumer T, Castiglione M (1989) Oyster reef as habitat for estuarine macrofauna. Technical Memorandum NMFS-SEFC-249. National Oceanic and Atmospheric Administration, Washington, D.C., USA.

Zu Ermgassen PSE, Hancock B, DeAngelis B, Greene J, Schuster E, Spalding M, Brumbaugh R (2016). Setting objectives for oyster habitat restoration using ecosystem services: a manager's guide. TNC, Arlington VA. pp 7. 
Figure 1

\section{Lifecycle of Ostrea edulis.}

Arrows with glow effect indicate stages that occur internally within the female oyster pallial (mantle) cavity, plain arrows indicate stages that occur externally. Approximate sizes and timings are based upon information from Hu et al. (1993), Acarli \& Lok (2009), FAO (2016) and, Loosanoff et al. (1966), Pascual (1972) and Tanaka (1981), cited within Hu et al. (1993). Images of life stages are not to scale.

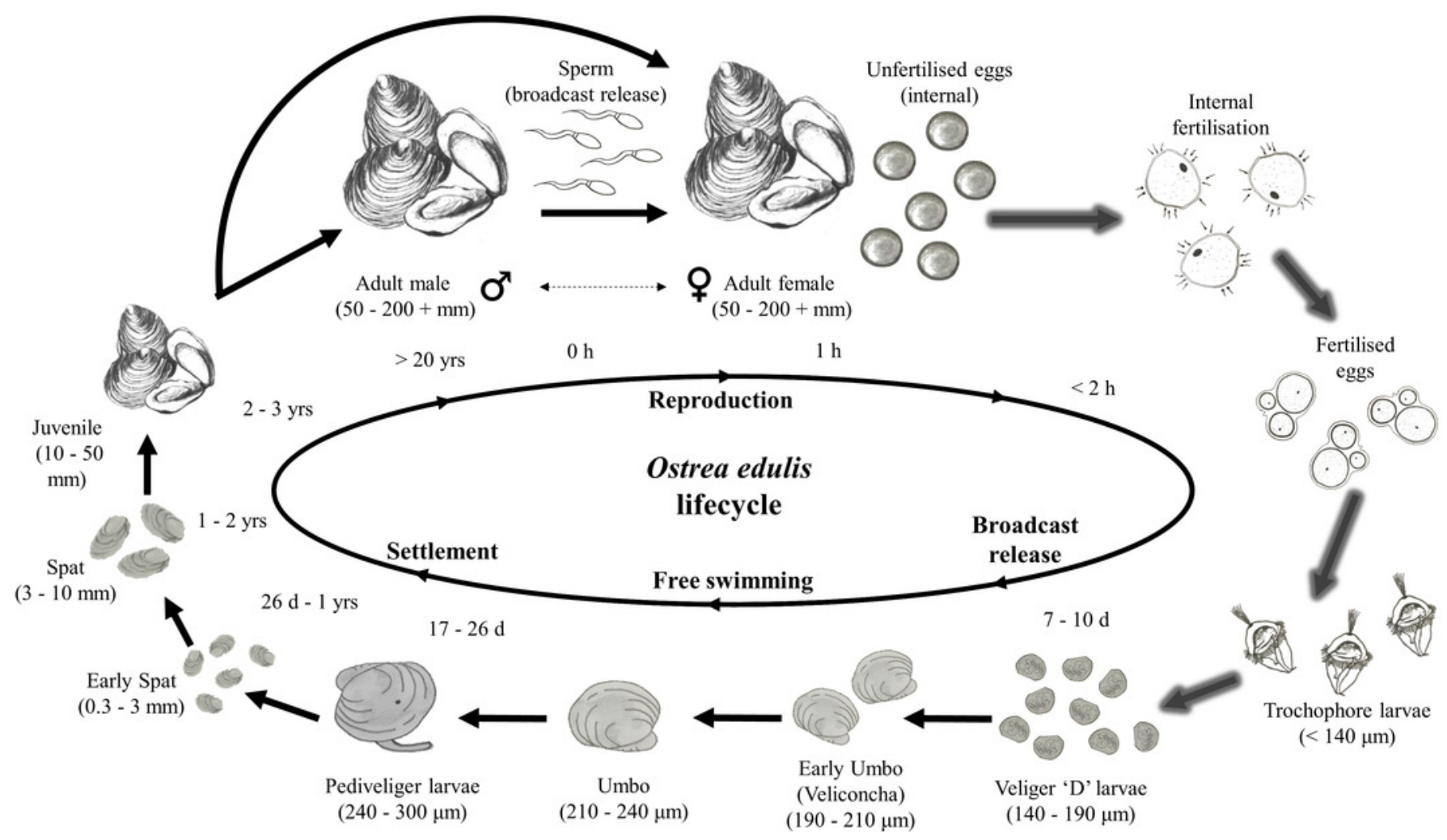


Figure 2

Interactive effects adversely affecting Ostrea edulis

The factors that are known to be adversely affecting Ostrea edulis populations within the Solent and their interconnecting relationships. Examples of the factors are shown where necessary.

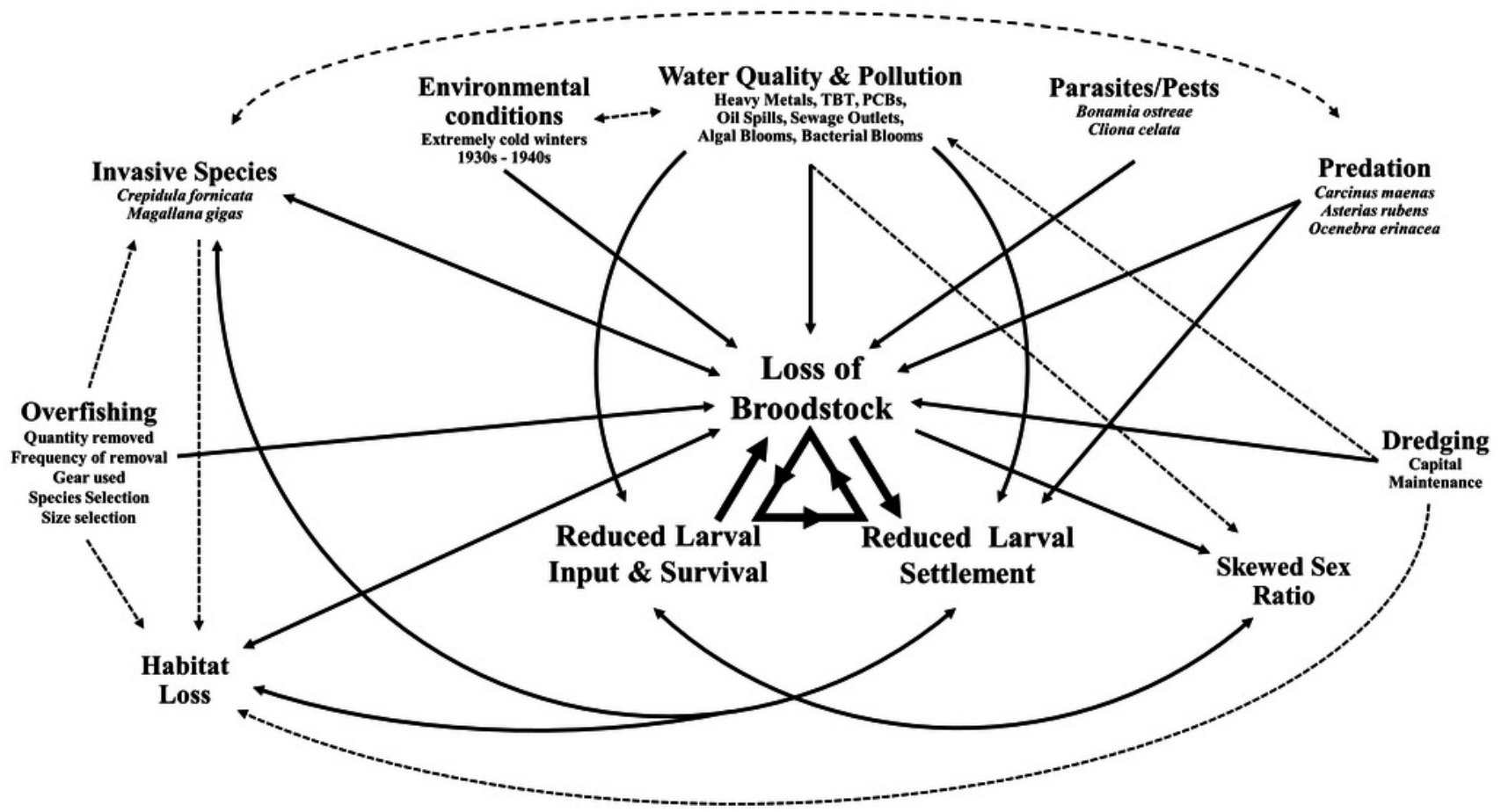

Direct Negative Impact on Population Indirect Negative Impact on Population 


\section{Figure 3}

Overview of Solent sampling locations.

(A) The wider Solent, showing the three harbours under investigation with locations of sample collection. (H+S) Hamilton Bank and Spit Bank, (S) Sinah Lake, (L) Langstone Channel, (E) Emsworth Channel, (T) Thorney Channel. (B) Benthic sample locations within Portsmouth, Langstone and Chichester harbours for the 2017 survey, three $0.1 \mathrm{~m}^{2}$ samples were retrieved from each area marked by a $\bigcirc$ with areas selected to cover the maximum amount of each harbour within reason. Maps created using ArcMap software.

*Note: Auto Gamma Correction was used for the image. This only affects the reviewing manuscript. See original source image if needed for review. 


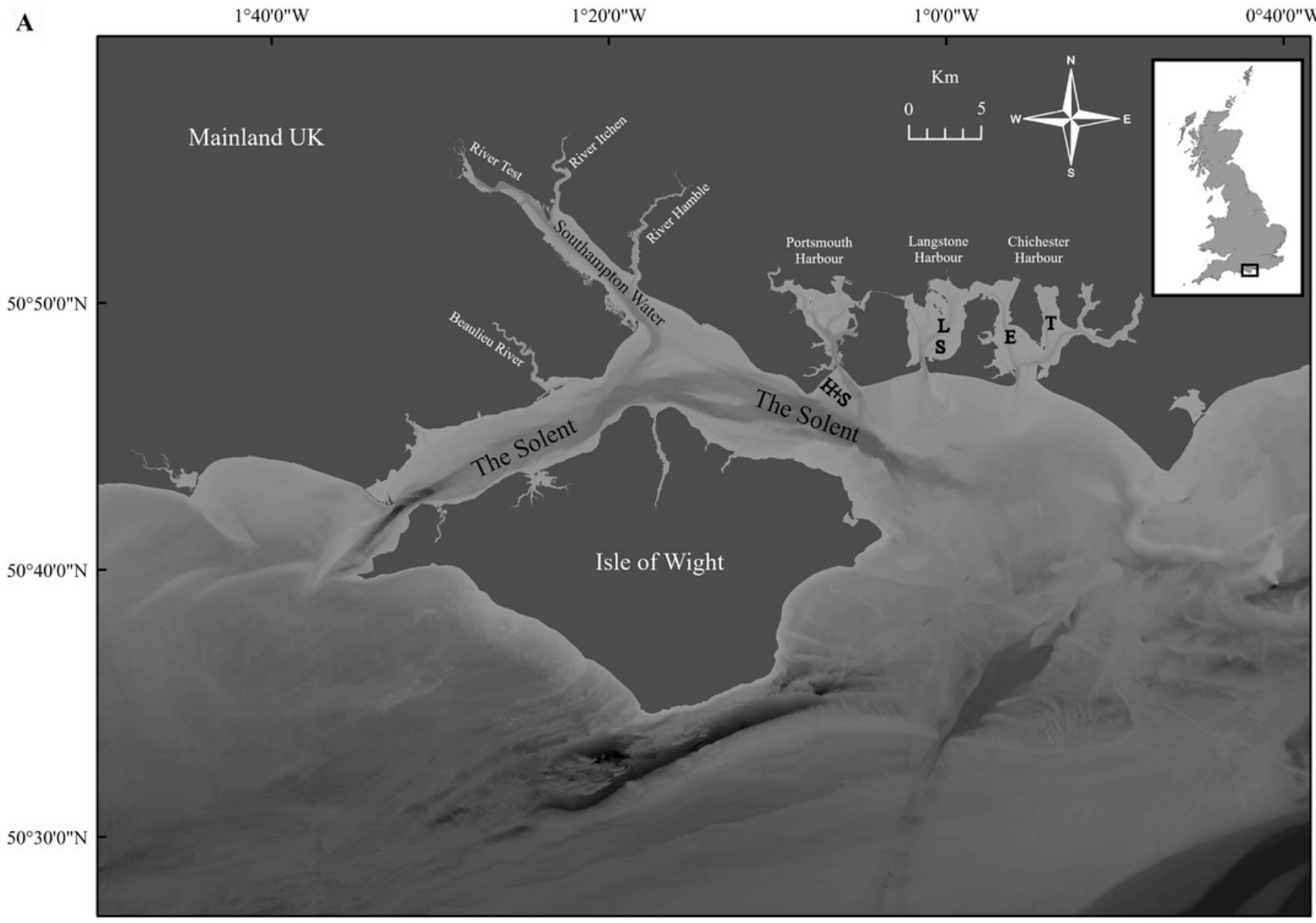

$1^{\circ} 10^{\prime} 0 " \mathrm{~W}$

$1^{\circ} 0$ 0"W

$0^{\circ} 50^{\prime} 0 " \mathrm{~W}$

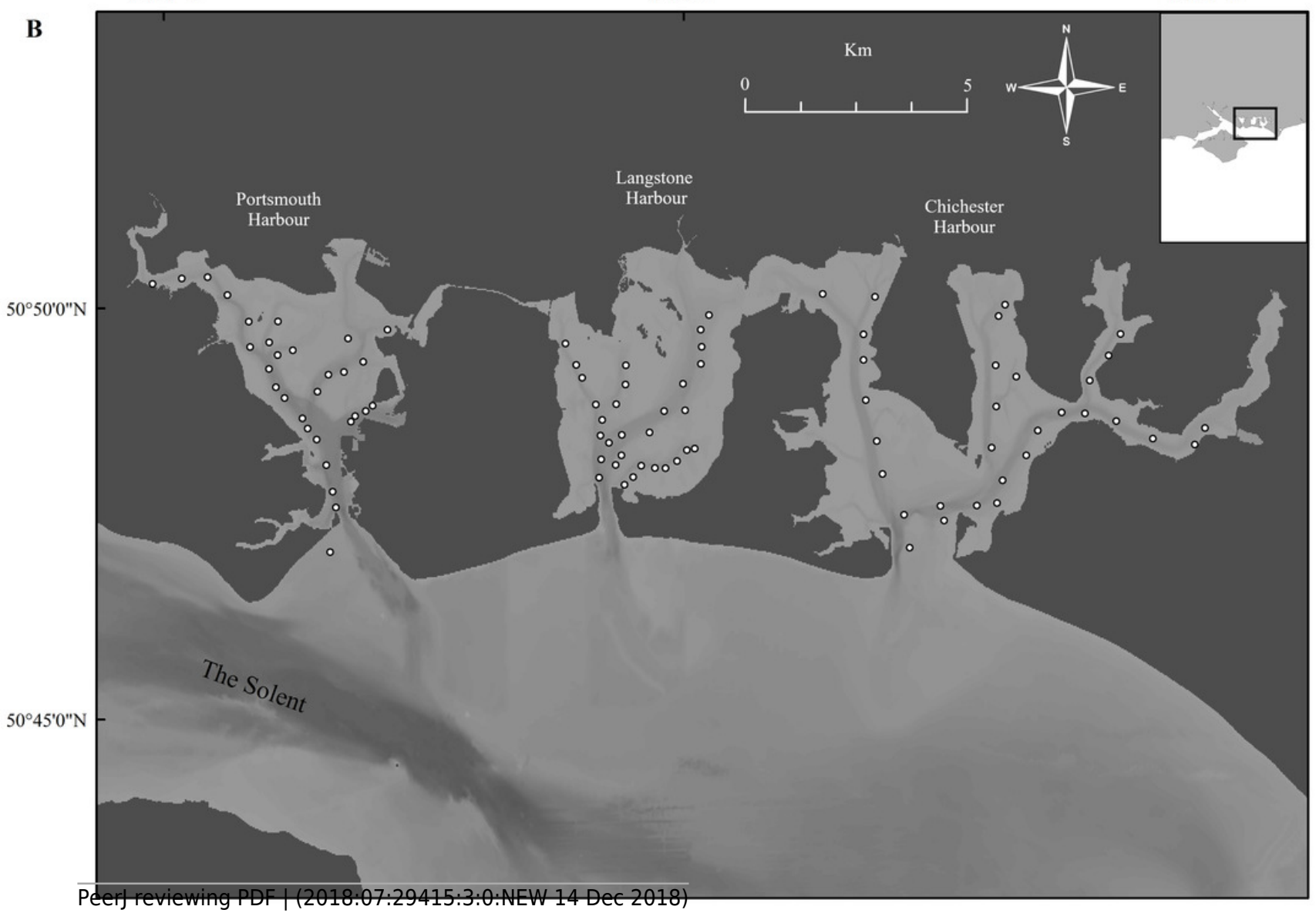




\section{Figure 4}

Morphometric measurements of Solent oysters

(A) Morphometric measurements recorded for Ostrea edulis. Box plots of morphometric parameters (Interquartile range, median and range of maximum shell $(B)$ length, $(C)$ width, (D) depth, $\mathrm{mm}$ and (E) whole wet weight, $\mathrm{g}$ ) for Ostrea edulis populations $(n=700)$ across eastern Solent harbours during 2015 - 2017. 
A
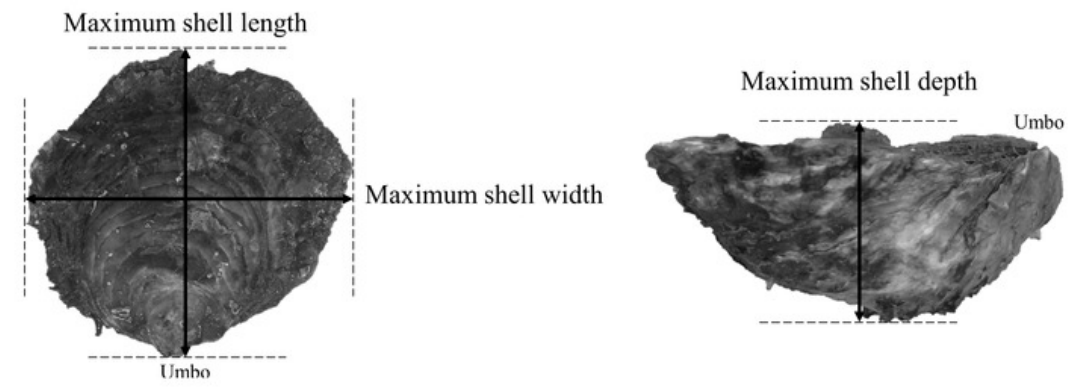

B

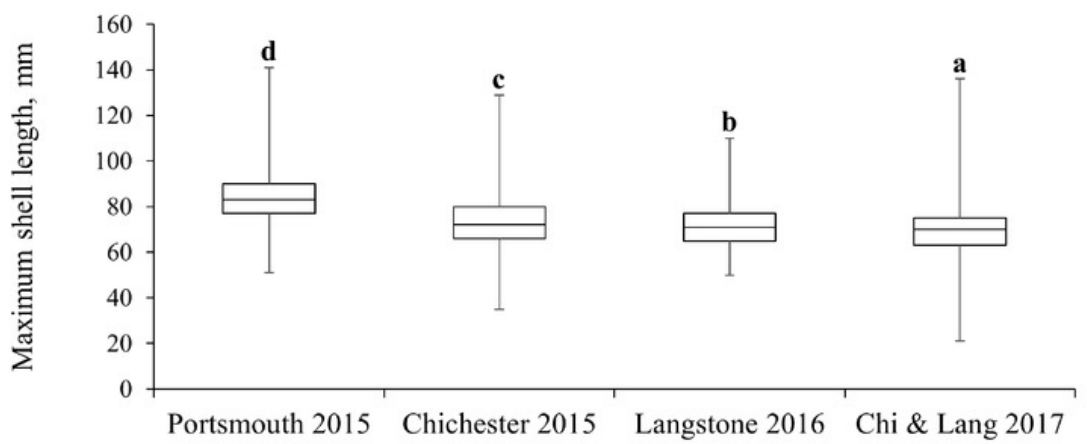

C

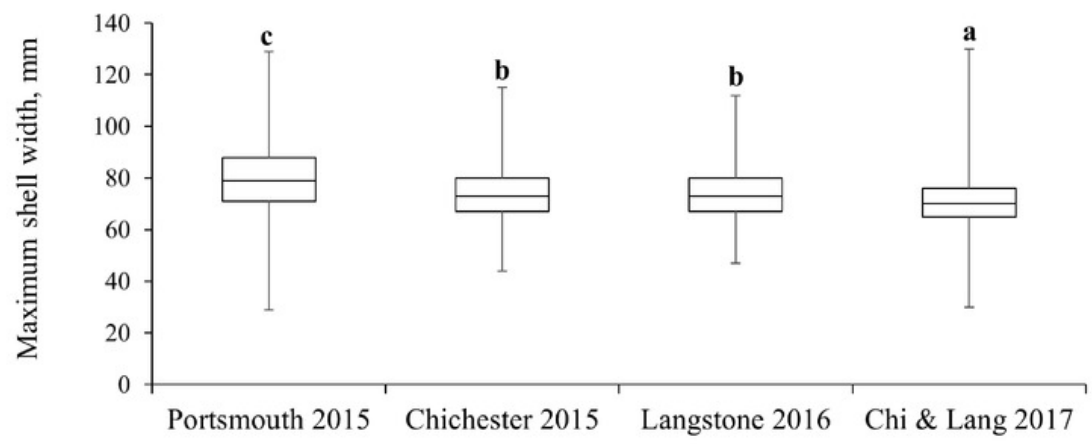

D

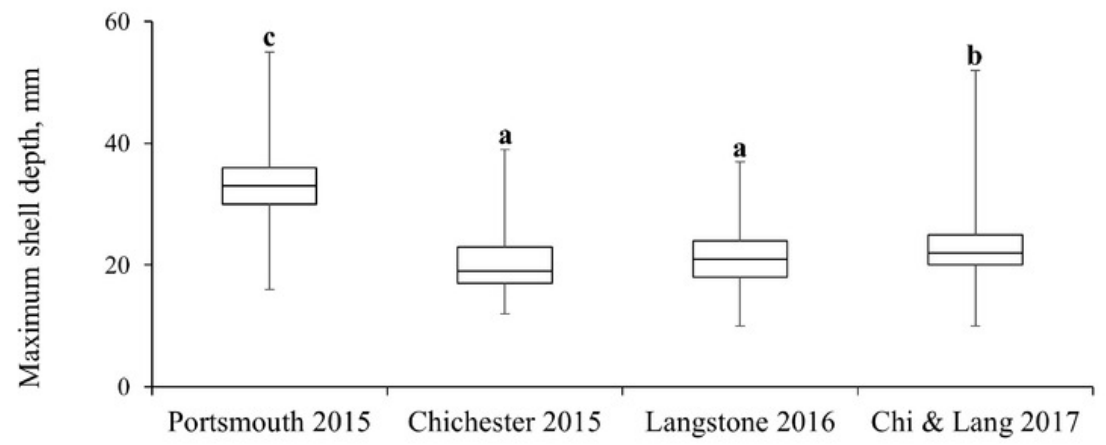

$\mathbf{E}$

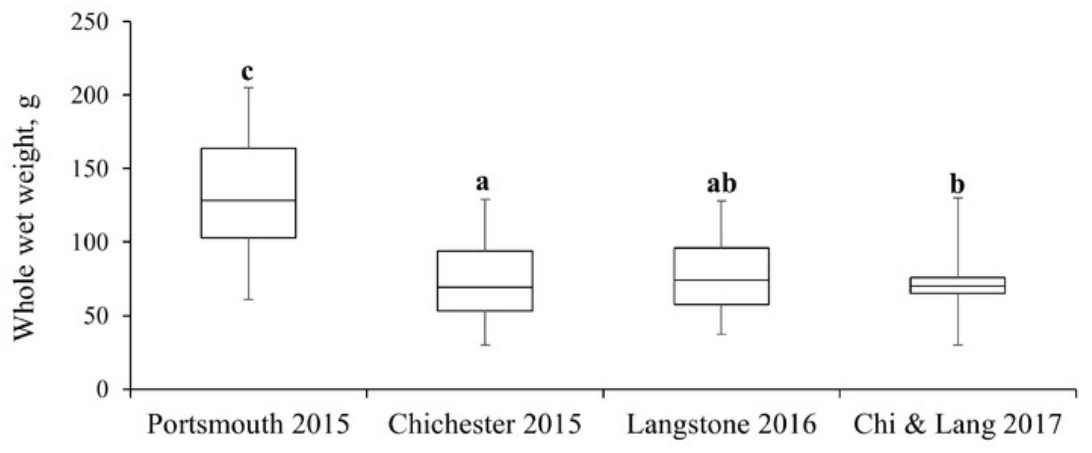




\section{Figure 5}

Native oyster population demographics.

Maximum mean length percentage frequency (with $5 \mathrm{~mm}$ intervals) of Ostrea edulis populations ( $n=700$ minimum) from East Solent harbours. 
Portsmouth 2015

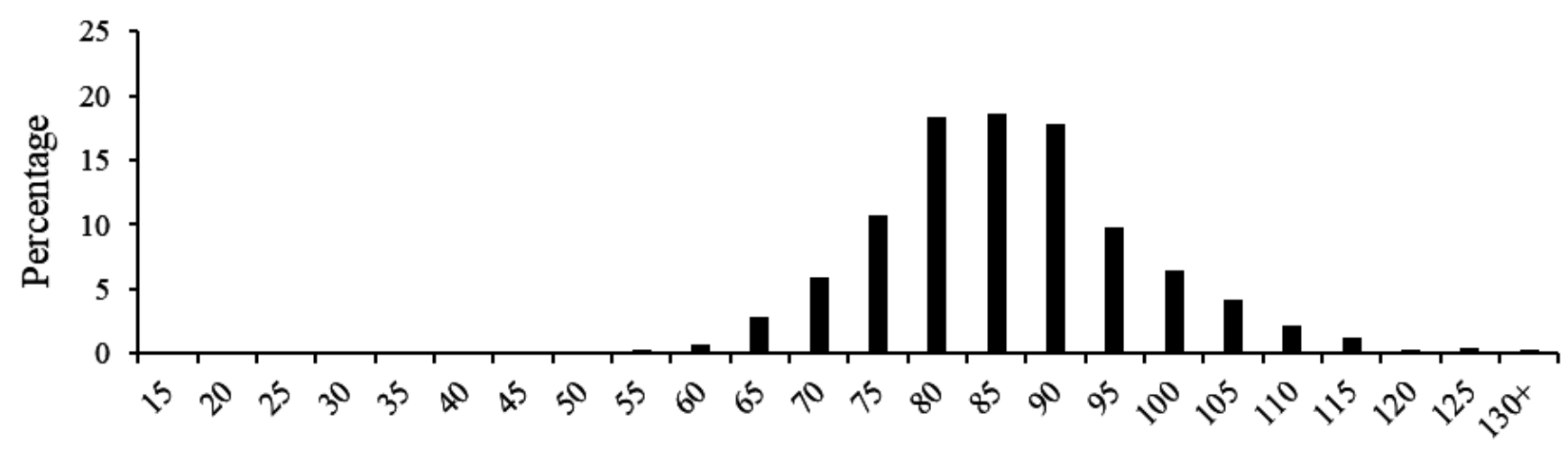

Chichester 2015

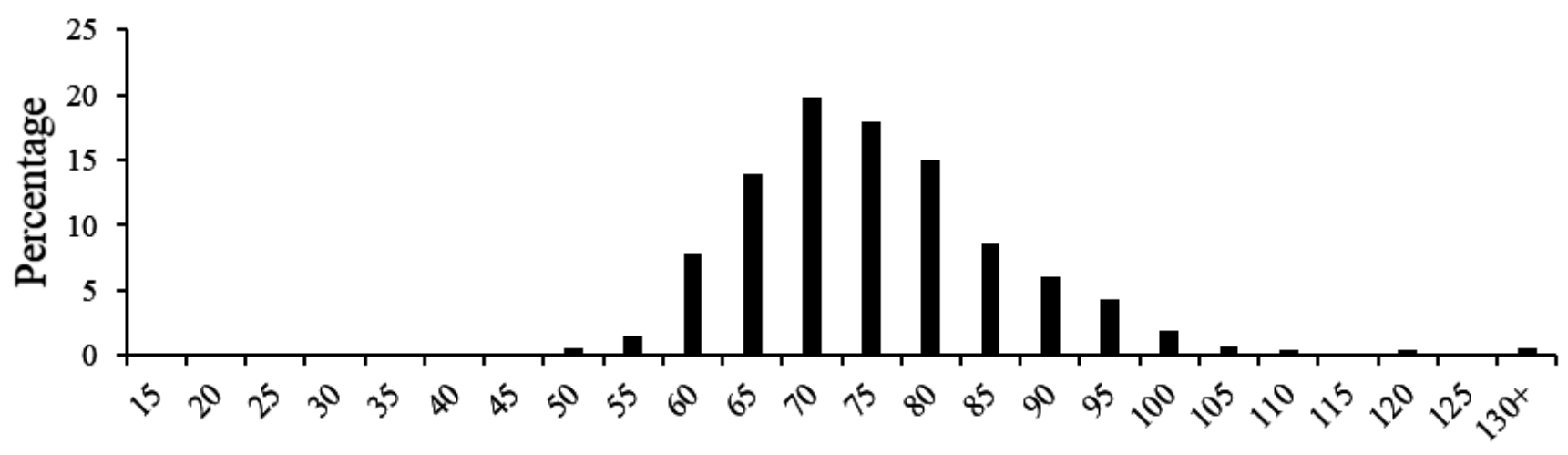

Langstone 2016

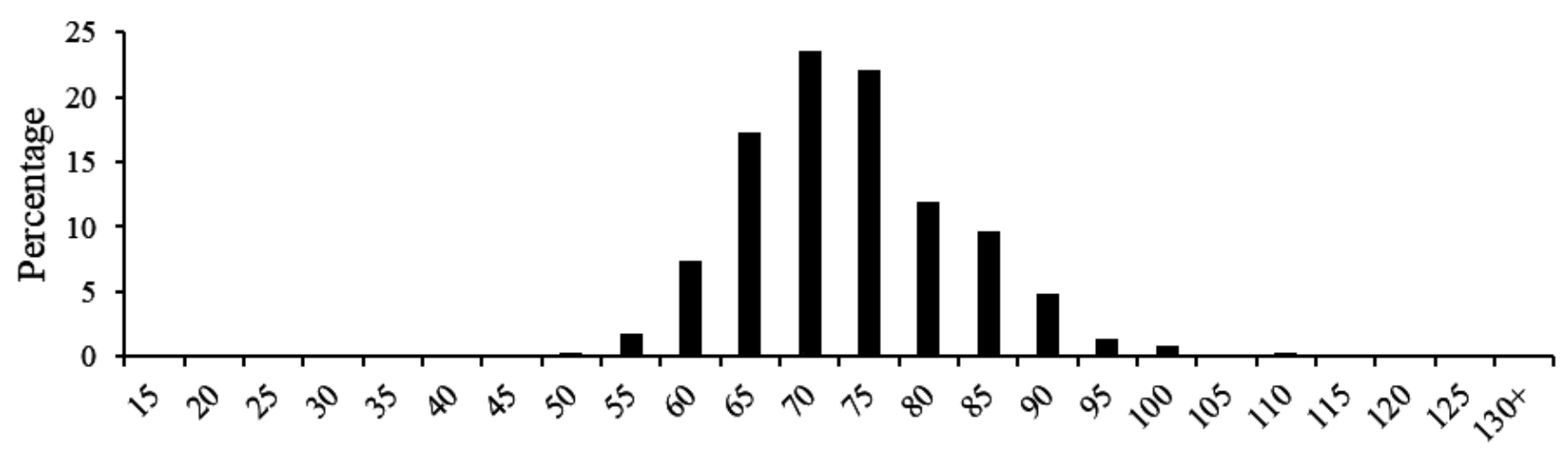

Chichester \& Langstone 2017

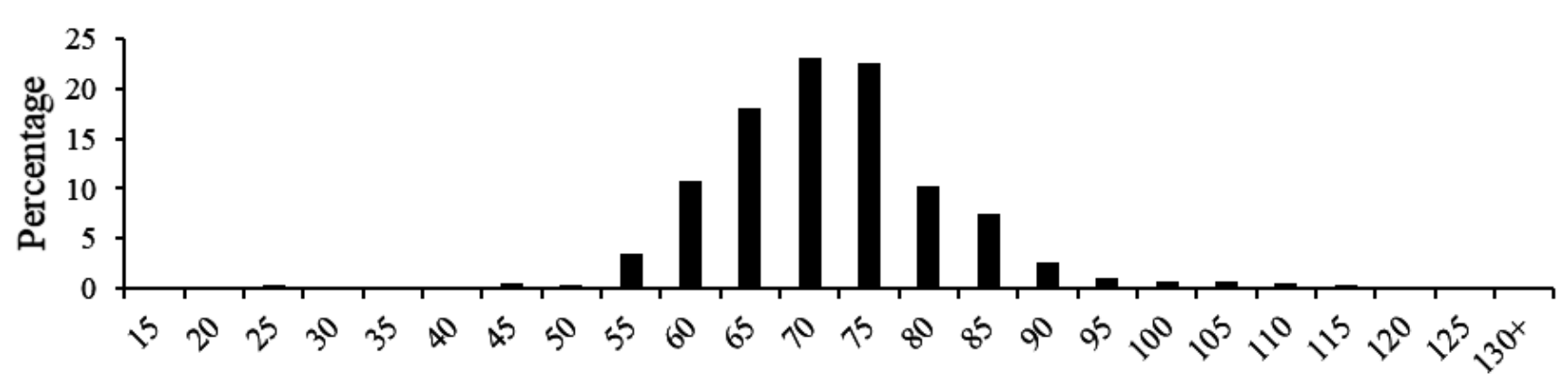




\section{Figure 6}

Native oyster and slipper limpet distributions within the Solent harbours during 2017

(A) Mean densities of Ostrea edulis at the sampling locations in Portsmouth, Langstone and Chichester harbours, 2017. (B) Mean densities of Crepidula fornicata at the sampling locations in Portsmouth, Langstone and Chichester harbours, 2017. Maps created using ArcMap software. 

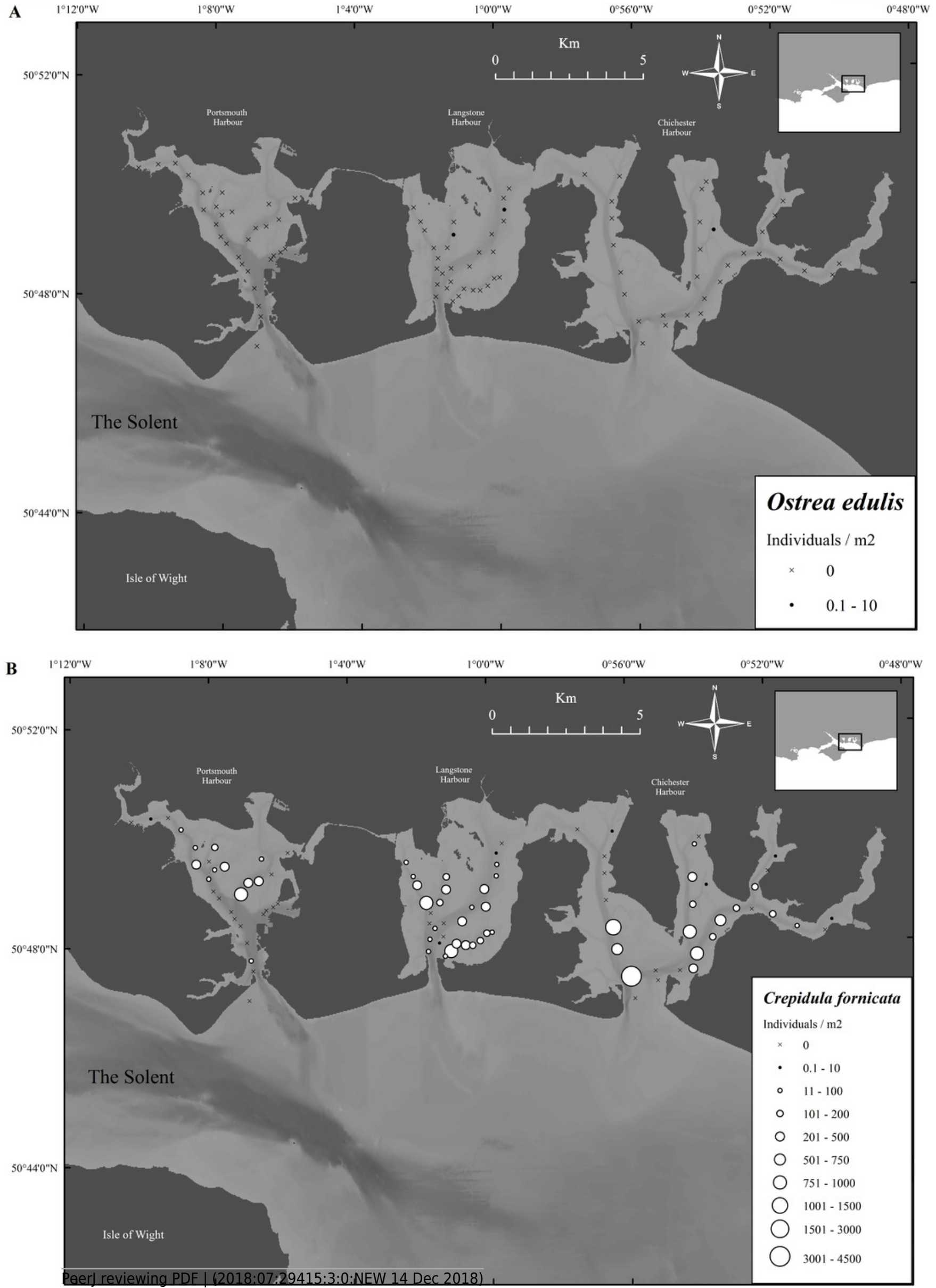


\section{Figure 7}

Temporal change in native oyster and slipper limpet distributions over 19 years.

(A) Densities of Ostrea edulis in Chichester harbour, 1998. (B) Change in Ostrea edulis densities in Chichester Harbour from 1998 to 2017. (C) Densities of Crepidula fornicata in Chichester harbour, 1998. (D) Change in Crepidula fornicata densities in Chichester Harbour from 1998 to 2017. Maps created using ArcMap software. 

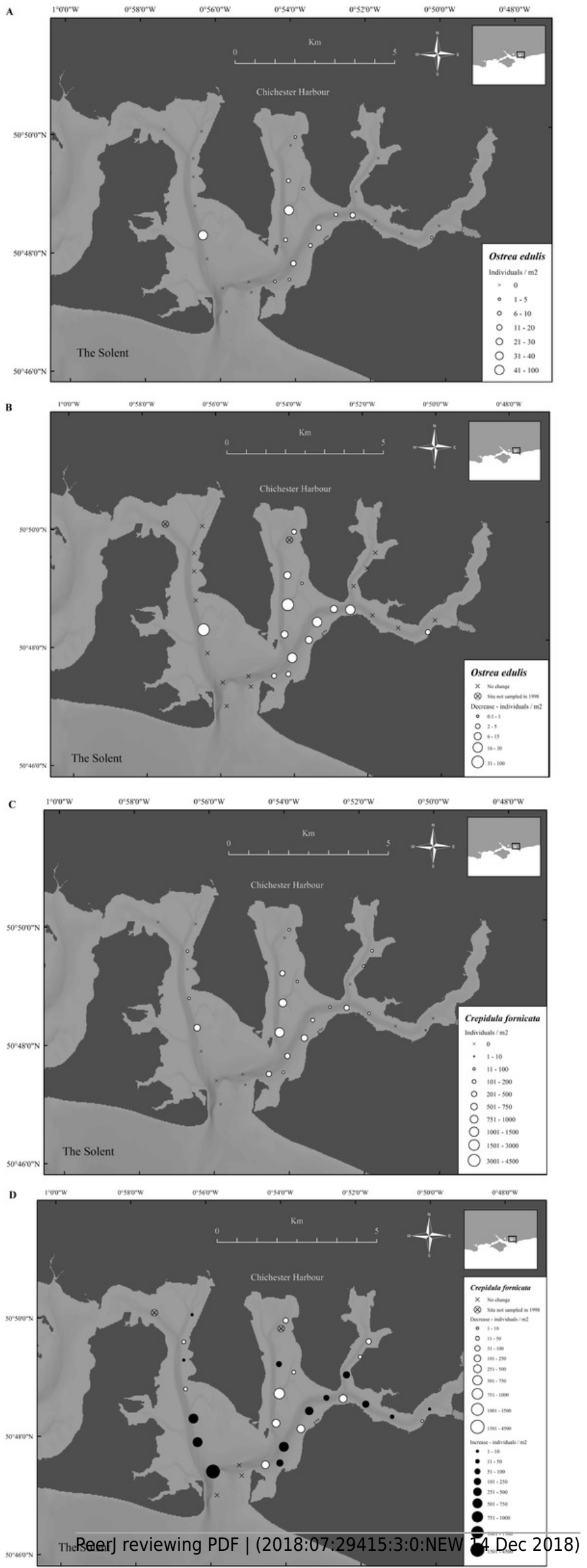


\section{Table $\mathbf{1}$ (on next page)}

Comparison of fishery population morphometrics

Fishery demographic data comparison between year groups across the three Eastern Solent harbours. 


\begin{tabular}{|c|c|c|c|c|c|}
\hline Morphometrics & $\begin{array}{l}\text { Portsmouth } \\
2015\end{array}$ & $\begin{array}{c}\text { Chichester } \\
2015\end{array}$ & $\begin{array}{l}\text { Langstone } \\
2016\end{array}$ & $\begin{array}{c}\text { Langstoned } \\
\text { Chichester } 2017\end{array}$ & $\begin{array}{c}\text { Statistical difference } \\
\text { between all group means } \\
\text { across site/year }\end{array}$ \\
\hline $\begin{array}{l}\text { Length } \mathrm{mm} \\
\text { mean } \pm \mathrm{SE}\end{array}$ & $84.27 \pm 0.44$ & $73.85 \pm 0.45$ & $70.02 \pm 0.36$ & $69.96 \pm 0.38$ & $\mathrm{~F}_{3,2853}=259, P \leq 0.001$ \\
\hline $\begin{array}{l}\text { Width mm } \\
\text { mean } \pm \mathrm{SE}\end{array}$ & $79 \pm 0.48$ & $73.84 \pm 0.39$ & $71.02 \pm 0.34$ & $70.88 \pm 0.36$ & $\mathrm{~F}_{3,2853}=89.8, P \leq 0.001$ \\
\hline $\begin{array}{l}\text { Depth } \mathrm{mm} \\
\text { mean } \pm \mathrm{SE}\end{array}$ & $33.1 \pm 0.41$ & $20.29 \pm 0.33$ & $23.03 \pm 1.53$ & $23.13 \pm 0.24$ & $\mathrm{~F}_{3,1853}=305.9, P \leq 0.001$ \\
\hline $\begin{array}{l}\text { Weight g } \\
\text { mean } \pm \mathrm{SE}\end{array}$ & $139 \pm 2.34$ & $79.42 \pm 1.54$ & $85.72 \pm 1.52$ & $87.22 \pm 2.46$ & $\mathrm{~F}_{3,2853}=329.4, P \leq 0.001$ \\
\hline
\end{tabular}




\section{Table 2 (on next page)}

Computed modal mean \pm SD length $(\mathrm{mm})$ cohort estimates

Computed modal mean \pm SD length $(\mathrm{mm})$ cohort estimates from length frequency analysis of all samples. $\mathrm{n}=$ population. 


\begin{tabular}{|c|c|c|c|c|c|c|c|c|}
\hline & \multicolumn{2}{|c|}{ Portsmouth 2015 } & \multicolumn{2}{c|}{ Chichester 2015 } & \multicolumn{2}{c|}{ Langstone 2016 } & \multicolumn{2}{c|}{$\begin{array}{c}\text { Langstone \& } \\
\text { Chichester 2017 }\end{array}$} \\
\hline Cohort/age class & Mean \pm SD & $\mathrm{n}$ & Mean \pm SD & $\mathrm{n}$ & Mean \pm SD & $\mathrm{n}$ & Mean \pm SD & $\mathrm{n}$ \\
\hline 1 & $84.57 \pm 9.67$ & 652 & $71.73 \pm 8.18$ & 559 & $69.12 \pm 6.18$ & 400 & $71.20 \pm 8.78$ & 743 \\
\hline 2 & $107.62 \pm 6.26$ & 43 & $89.35 \pm 8.66$ & 133 & $79.08 \pm 8.76$ & 300 & $103.33 \pm 6.53$ & 14 \\
\hline 3 & $126.97 \pm 2.65$ & 5 & $124.19 \pm 6.28$ & 8 & & & & \\
\hline
\end{tabular}

